\title{
LIMITING THE PROPERTy CLAUSE
}

\begin{abstract}
Jeffrey M. Schmitt*
The Supreme Court has repeatedly held that the Property Clause of the Constitution grants Congress the power to regulate the public lands "without limitation." This Article argues that the Court's interpretation of the Property Clause is inconsistent with constitutional history, antithetical to structure principles of federalism, and undesirable from the standpoint of environmental law. When the country originally debated the meaning of the Property Clause, the leading statesmen of the early Republic rejected a broad interpretation of federal power. They believed that, while Congress had a police power over the territories, it had no more regulatory authority over federal land within a state by virtue of the Property Clause than a private landowner. If the Court's recent efforts to revive federalism are to be meaningful, it should return to this original understanding. Congress's unlimited legislative power over federal lands enables it to overrule state policy on many of the core issues of state concern that justify the existence of federalism, including environmental law. Perhaps counterintuitively, reinvigorating federalism in this context would also structurally favor more robust environmental regulation. This is because, while the federal government would retain the power to limit the use of its lands as a proprietor, the states would have the power to go further as sovereign regulators. However, because the state's regulatory power would not include the power to override federal property rights, the states would not have the power to authorize any land use that would conflict with federal rules. Unlike the current system of federal supremacy, a limited reading of the Property Clause would thus structurally favor conservation over development.
\end{abstract}

\section{TABLE OF CONTENTS}

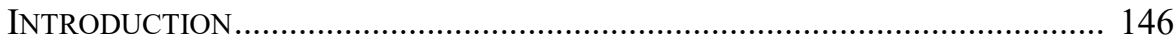

I. TEXT AND FRAMERS' INTENT ……................................................ 151

A. The Text and Structure of the Constitution .................................. 151

B. Original Intent .................................................................... 154

II. Constitutional History: Beyond the Founding And Court

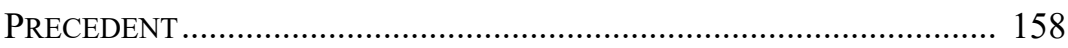

A. Tennessee …...................................................................... 159

B. The Enabling Acts and Missouri Crisis .................................. 160

* Associate Professor of Law, University of Dayton School of Law. I would like to thank Blake Watson, Christopher Roederer, Erica Goldberg, the participants at the Loyola University Constitutional Law Colloquium, and the participants at faculty workshops at the University of Cincinnati College of Law and University of Toledo College of Law for their helpful comments and suggestions. 
C. Western Demands for Cession ............................................... 162

D. Native American Sovereignty....................................................... 167

III. Judicial PRECEDENT: The Property Clause IN THE SUPREME

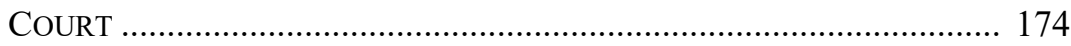

A. Antebellum Cases.............................................................. 174

B. Reconstruction to New Deal ...................................................... 179

C. The New Deal to Today ............................................................. 186

IV. Structure: The Property Clause AND Federalism .................... 188

A. New Federalism .............................................................. 188

B. Equal Sovereignty ......................................................... 191

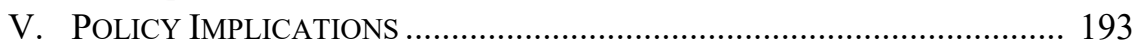

A. The Property Clause and Environmental Law ........................... 193

B. Other Issues: Federal Land Ownership, Tribal Sovereignty,

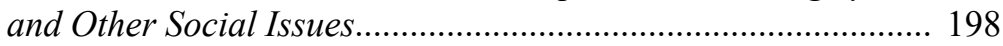

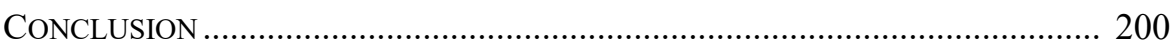

\section{INTRODUCTION}

In spite of the principle that Congress is limited to its enumerated powers, the federal government effectively has a police power over one-third of the country. This power arises from the Property Clause of the Constitution, which grants Congress the power to "make all needful Rules and Regulations respecting the Territory or other Property belonging to the United States[.]"1 The Supreme Court has repeatedly held that Congress's legislative authority under the Property Clause is "without limitations." 2 This expansive power extends to 640 million acres of federal land, most of which is located in the West. ${ }^{3}$ Although the Property Clause is generally ignored in the study of constitutional law, ${ }^{4}$ it is

1 U.S. CONST. art. IV $\S 3$, cl. 2. This Clause is also known as the "Territories Clause." Ngiraingas v. Sanchez, 495 U.S. 182, 203 (1990) (Brennan, J., dissenting). The Enclave Clause further grants Congress a power of "exclusive [1] egislation" over federal land purchased with the consent of a state. See U.S. ConST. art. I, § 8, cl. 17. Although the Enclave Clause applies to most federal buildings, military bases, and some national parks, the vast majority of federal land is governed exclusively by the Property Clause. See Charles F. Wilkinson, CrossJurisdictional Conflicts: An Analysis of Legitimate State Interests on Federal and Indian Lands, 2 UCLA J. ENVTL. L. \& POL'Y 145, 148-49, 152 (1982).

2 See Kleppe v. New Mexico, 426 U.S. 529, 535, 539 (1976).

3 See Carol H. Vincent et al., Federal Land Ownership: Overview and Data 1, 4, 6, 7, 21 (2017), https://fas.org/sgp/crs/misc/R42346.pdf [https://perma.cc/3QGG-K74H]. The United States owns and manages roughly 640 million acres of land. $I d$. at 1 . This represents approximately 61.3 percent of the land in Alaska and 46.4 percent of the land in eleven contiguous western states. $I d$. at 7, 20, 21. In fact, 79.6 percent of the land in Nevada is owned by the United States. $I d$. at 7.

4 No leading textbook devotes a single case to the study of the Property Clause. See generally Erwin Chemerinsky, Constitutional Law (5th ed. 2017); Geoffrey R. Stone et. AL., CONSTiTutional LAW 742, 967-68, 1039 (7th ed. 2013). 
thus a significant source of federal authority. In fact, the federal government uses its land ownership to justify overriding state policy on topics ranging from wildlife management ${ }^{5}$ to the oversight of care for unaccompanied migrant children. ${ }^{6}$

This Article will argue that the Court's expansive interpretation of the Property Clause is inconsistent with constitutional history, antithetical to structure principles of federalism, and undesirable as a matter of policy. It therefore will present a new approach to the Property Clause that both accommodates the reality of widespread federal land ownership and imposes limits on federal regulatory power. ${ }^{7}$ Although legal history is at the core of this Article, its interpre-

5 See Kleppe, 426 U.S. at 532-34.

${ }^{6}$ Federal authorities rejected state oversight of a facility in Homestead, Florida on the grounds that it is located on federal land. See John Burnett, Inside the Largest and Most Controversial Shelter for Migrant Children in the U.S., NPR (Feb. 13, 2019), https://www.npr.

org/2019/02/13/694138106 [https://perma.cc/E4QC-EP66]. The federal government took the same position with respect to a shelter located on federal land in Tornillo, Texas before its recent closure. Pursuant to federal law, however, shelters for migrant children are typically subject to state standards and inspections. See Graham Kates, Some Detention Centers for Migrant Children not Subject to State Inspections, CBS NEws (July 5, 2018), https://www.cbsnews.com/news/some-detention-centers-for-immigrant-children-wont-be-su bject-to-traditional-inspections [https://perma.cc/R2X7-T5CE]. These particular facilities are likely located on federal enclaves, but the Court's modern Property Clause doctrine would enable the federal government to exclude state oversight of migrant shelters on any federally owned land. Id.

7 Most recent scholarship on the Property Clause has focused on the power of the United States to own land within the states. See Gregory Ablavsky, The Rise of Federal Title, 106 CALIF. 631, 684 (2018); Ian Bartrum, Searching for Cliven Bundy: The Constitution and Public Lands, 2 NeV. L.J.F. 67, 72 (2018); John D. Leshy, Are U.S. Public Lands Unconstitutional?, 69 Hastings L.J. 499, 553 (2018); Jeffery Schmitt, A Historical Reassessment of Congress's "Power to Dispose of" the Public Lands, 42 HARv. EnvTL. L. Rev. 453, 455 (2018). When scholars discuss Congress's power to regulate activities on federal land, they nearly always support the Court's broad interpretation. See, e.g., Peter A. Appel, The Power of Congress "Without Limitation": The Property Clause and Federal Regulation of Private Property, 86 MinN. L. Rev. 1, 15 (2001); Michael C. Blumm \& Olivier Jamin, The Property Clause and its Discontents: Lessons from the Malheur Occupation, 43 Ecology L.Q. 781, 801 (2016); Eugene R. Gaetke, Refuting the "Classic” Property Clause Theory, 63 N.C. L. Rev. 617, 620 (1985); Dale D. Goble, The Myth of the Classic Property Clause Doctrine, 63 Denv. U. L. Rev. 495, 498 (1986) hereinafter [Goble, The Myth of the Classic Property Clause Doctrine]; Dale D. Goble, The Property Clause: As if Biodiversity Mattered, 75 U. Colo. L. Rev. 1195, 1200-01 (2004) hereinafter [Goble, The Property Clause]; Nick Lawton, Utah's Transfer of Public Lands Act: Demanding a Gift of Federal Lands, 16 VT. J. ENVTL. L. 1, 22 (2014); Martin Nie et al., Fish and Wildlife Management on Federal Lands: Debunking State Supremacy, 47 ENVTL L. 797, 819-20 (2017). Many other scholars discuss the Court's interpretation with approval. Ablavsky, supra, at 692; Jessica Owley, Taking the Public Out of Public Lands: Shifts in Coal-Extraction Policies in the Trump Administration, 13 FIU L. REV. 35, 38 (2018). The few scholars who argue for a more limited reading of Congress's regulatory power under the Property Clause generally also contend that Congress was historically understood to have had a constitutional duty to divest itself of the federal land within the states. Albert W. Brodie, A Question of Enumerated Powers: Constitutional Issues Surrounding Federal Ownership of the Public Lands, 12 PAC. L.J. 693, 703 (1981); David E. Engdahl, State and Federal Power Over Federal Property, 18 ARIZ. L. REV. 283, 
tation of the Property Clause is based on several modalities of constitutional argument, including text, original intent, history, precedent, structure, and policy, rather than any particular theory of constitutional interpretation. ${ }^{8}$ This approach represents a significant break from past scholarship, which has virtually ignored constitutional history outside the founding period and Supreme Court precedent. ${ }^{9}$ This Article is also the first to make the counter-intuitive claim that limiting federal power under the Property Clause would create a system that structurally favors conservation over the use and development of federal land.

In sum, this Article will argue that, while Congress should have a police power over the federal territories, it should have no more regulatory authority over federal land within a state by virtue of the Property Clause than a private landowner. Under this approach, Congress could continue to limit activities on federal lands, just as any landowner can exclude trespassers. When acting solely under the Property Clause, however, Congress would not have the ability to preempt otherwise valid state regulations. Unless authorized pursuant to the Commerce Clause or another enumerated power, activities on federal land would therefore need to be consistent with both state and federal law. For example, even if the federal government used its power as a landowner to authorize a company to pollute on federal land, the state would have the power to block such activities as a sovereign regulator. ${ }^{10}$ Unlike the Court's modern doctrine, this approach to the Property Clause is faithful to constitutional history, is consistent with the Court's federalism revolution, and would structurally favor environmental conservation.

This interpretation of the Property Clause is based on constitutional history. When the country first debated the meaning of the Property Clause, the leading statesmen of the early Republic rejected expansive federal regulatory power over the public lands within a state. ${ }^{11}$ After the first new states were admitted to the Union, westerners demanded that Congress cede title to all land within each state's borders. Failing to do so, these westerners contended, violated the fundamental constitutional requirement of equal state sovereignty. Congressional leaders responded by arguing that the western states retained equal political power because federal land ownership did not confer any greater legislative authority on Congress than that of an ordinary proprietor. Continued federal land ownership was therefore predicated on a limited understanding of Congress's regulatory power under the Property Clause. Although scholars

294 (1976); Carolyn M. Landever, Whose Home on the Range? Equal Footing, the New Federalism and State Jurisdiction on Public Lands, 47 FLA. L. REv. 557, 559 (1995).

${ }^{8}$ For more on the standard forms of constitutional argument, see PHILIP BoBBitT, CONSTITUTIONAL INTERPRETATION 12-13 (1991). The author's goal is to present an argument that will be accepted by originalists and living constitutionalists alike. Id.

9 See supra note 7 and accompanying text. Professor Ablavsky is a notable exception. However, his article primarily discusses the nature of federal title to the land rather than Congress's regulatory power under the Property Clause. See Ablavsky, supra note 7, at 635.

10 Because the federal government would be acting only as a landowner, it would lack the power to preempt state law when acting solely under the Property Clause.

11 See Schmitt, supra note 7 at $475-78$. 
have examined these congressional debates in other contexts, ${ }^{12}$ this Article is the first to use them to interpret Congress's powers under the Property Clause.

Placing the Supreme Court's precedent within the context of these larger and more publicly visible congressional debates helps to resolve a longstanding scholarly dispute. The Court's early cases did not directly rule on the scope of Congress's regulatory power under the Property Clause, and scholars have parsed the Court's dicta to reach dramatically different conclusions. ${ }^{13}$ Because congressional leaders publicly endorsed a limited view of the Property Clause, it is likely that the Court shared similar views. In fact, this Article will argue that the Court did not clearly endorse a broad view of federal power until the New Deal constitutional revolution of the early twentieth century.

Structural principles of federalism also support this Article's interpretation. The Property Clause is rarely invoked today because most federal legislation, including environmental law, is justified under a broad reading of the Commerce Clause. ${ }^{14}$ If the Commerce Clause conferred unlimited power on Congress, the Court's ahistorical reading of the Property Clause would be of no importance. Over the past several decades, however, the Court has begun to limit congressional power to preserve a zone of autonomy for the states..$^{15}$

The Court's expansive reading of the Property Clause, however, empowers Congress to sidestep these limitations on federal power and effectively overrule state policy on many of the core social issues that justify the existence of federalism. ${ }^{16}$ By the same logic, if the Court were to reverse Roe v. Wade, and a state criminalized abortion, Congress arguably could authorize the construction of abortion clinics on federal land within each state. Congress also could legalize gambling, drug use, physician-assisted suicide, and prostitution on federal land. ${ }^{17}$ More realistically, the federal government could-and sometimes does - overrule state efforts to protect wildlife, the environment, and natural

12 See, e.g., Daniel Feller, The Public Lands in Jacksonian Politics xvi (1984); Paul W. Gates, History of Public Land Law Development 9 (1968); John R. Van Atta, Securing the West: Politics, Public Lands, and the Fate of the Old Republic 178518506 (2014); Raynor G. Wellington, Preface to The Political and Sectional Influence OF THE Public LANDs 1828-1842 (1914). These historical works are broadly concerned with public land policy rather than the history of constitutional argument.

13 Compare Appel, supra note 7, at 30-36, Gaetke, supra note 7, at 639-45, and Goble, The Myth of the Classic Property Clause Doctrine, supra note 7, at 502-11, with Brodie, supra note 7, at 712-15, and Engdahl, supra note 7, at 358-62.

14 See Christine A. Klein, The Environmental Commerce Clause, 27 HARV. EnVTL. L. REV. 1, 66 (2003); Owley, supra note 7, at 37.

15 See infra Section IV.A.

16 See generally supra text accompanying notes 5 \& 6. In 2017, California passed legislation directing the state attorney general to inspect detention facilities used to hold noncitizens for purposes of immigration enforcement. The U.S. District Court for the Eastern District of California denied the federal government's motion to enjoin the law and held that the California attorney general is entitled to access. See United States v. California, No. 2:18-cv490-JAM-KJN, 2018 WL 3361055, at *2 (E.D. Cal. July 9, 2018).

17 See Appel supra note 7, at 5 (raising similar hypotheticals and arguing that they should be constitutional under the Property Clause). 
resources. ${ }^{18}$ Although Congress could directly achieve many of these same goals today under the Commerce Clause and its other enumerated powers, the Court's broad reading of the Property Clause would undermine any future limitations it places on federal power.

In fact, limiting the Property Clause would have an immediate impact on issues that cannot be regulated under the Commerce Clause today. For example, suppose that a wetland located on U.S. land was wholly located within one state and did not connect to any navigable water. Although the Clean Water Act (CWA) prohibits the discharge of pollution into the "waters of the United States," the Commerce Clause does not justify application of the CWA to isolated wetlands that lack a nexus to navigable waters. ${ }^{19}$ If the federal government were to regulate the discharge of pollutants into this hypothetical wetland, it would therefore be forced to rely on the Property Clause. Under the Court's current understanding of the Property Clause, federal authorization would preempt any conflicting state law. ${ }^{20}$ If this Article's interpretation of the Property Clause were adopted, however, the state could prohibit pollution of the wetland notwithstanding any contrary federal authorization. The inverse, though, would not hold. The federal government, like any other landowner, would be able to prevent the discharge of pollutants on its lands even if the discharge would otherwise comply with state law. Like a one-way ratchet, limiting the Property Clause would therefore merely provide an additional layer of protection for the environment. Although this example may seem inconsequential, the importance of the Property Clause will grow if, and when, the Court narrows the reach of the federal commerce power.

This example also highlights why this Article's interpretation of the Property Clause would enhance structural protections for the environment. ${ }^{21}$ Under most environmental statutes, the states are permitted to go beyond federal protections. ${ }^{22}$ However, this is merely a matter of legislative grace. When such

18 See Larry Voyles et Al., Ass'N Fish and Wildlife Agencies, Wildlife Management Authority: The State Agencies' Perspective 2 (2014).

19 See Rapanos v. United States, 547 U.S. 715, 722, 739, 742 (2006). Although Rapanos technically dealt with the reach of the CWA, the Court's interpretation of the statute was influenced by its understanding of the Commerce Clause. The "nexus" test is from Justice Kennedy's concurring opinion. Id. at 759 (Kennedy, J., concurring). Because no single opinion obtained a majority of the Court, Justice Kennedy's opinion, which is the narrowest, is most likely controlling. See Robert W. Adler, US Environmental Protection Agency's New Waters of the United States Rule: Connecting Law and Science, 34 FreshwATER SCI. 1595, 1598 (2015).

${ }^{20}$ See California Coastal Comm'n v. Granite Rock Co., 480 U.S. 572, 593 (1987).

21 This Article is the first to examine the practical consequences of a limited reading of the Property Clause. However, there is a robust debate within the environmental law community regarding the proper role of the states. See, e.g., William W. Buzbee, Contextual Environmental Federalism, 14 N.Y.U. ENVTL. L.J. 108, 110-12 (2005) (discussing the academic debate). This debate, however, is generally about which level of government should have the primary regulatory role. Both sides acknowledge that the federal government has the constitutional power to displace state policy. Id. This Article differs by arguing for constitutional limitations on federal power.

22 See id. at 126-27. 
laws are passed under the Commerce Clause, Congress always maintains the power to overrule state policy. If Congress acted exclusively under this Article's interpretation of the Property Clause, however, the states could regulate harmful activities on federal land in the same manner as activities on private land. Environmentally destructive land uses would thus be lawful only if authorized both by the federal government as a landowner and by the states as sovereign regulators. In other words, rather than giving absolute power to the federal government, each level of government would have the power to stop activities on federal land that cause harm to the state's environment. As recent moves by the Trump Administration have made clear, ${ }^{23}$ federal supremacy is not always synonymous with good policy or environmental protection.

The remainder of this Article is divided into five parts. Part I will review the text of the Property Clause and intent of the framers. Part II will develop the original understanding of the Clause through an analysis of several previously overlooked congressional debates. Part III will examine Supreme Court precedent and argue that it supported a limited understanding of federal power under the Property Clause until the New Deal Era. Part IV will argue that a limited interpretation of the Clause is more consistent with the Court's federalism jurisprudence. Part V will contend that this Article's approach would provide structural protections against undue environmental degradation.

\section{TEXT AND FRAMERS' INTENT}

Constitutional interpretation typically includes an analysis of the text, original intent, history, court precedent, and practical policy implications. ${ }^{24}$ The text and structure of the Constitution, however, do not resolve the issue of whether the Property Clause grants Congress an unlimited power to regulate federal land within the states. Moreover, because the federal government did not own a significant amount of land within the states at the time of the Founding, ${ }^{25}$ there is little evidence of original intent.

\section{A. The Text and Structure of the Constitution}

The Property Clause of Article IV states: "[t]he Congress shall have Power to dispose of and make all needful [r]ules and [r]egulations respecting the [t]erritory or other [p]roperty belonging to the United States[.]"26 Samuel John-

23 The Trump Administration has recently proposed weakening regulations under both the Endangered Species Act and the Clean Water Act. See Coral Davenport, Trump Rule Would Limit E.P.A. 's Control Over Water Pollution, N.Y. TIMES (Dec. 6, 2018), https://www.ny times.com/2018/12/06/climate/trump-water-pollution-wotus-replacement.html [https://perma.cc/L4KM-RDLN]; Michael Doyle, E\&E News, Trump Overhaul of Endangered Species Act Could Shrink Protections for Many Animals, Sci. Mag. (July 19, 2018), https://www.sciencemag.org/news/2018/07/trump-administration-proposes-endangered-spec ies-act-overhaul-could-shrink-critical [https://perma.cc/998J-MCKJ].

24 See BoBBitT, supra note 8.

25 See Schmitt, supra note 7, at 464.

26 U.S. CONST. art. IV, § 3, cl. 2. 
son's A Dictionary of the English Language, which is generally seen as the most authoritative founding era dictionary, ${ }^{27}$ defines "Territory" as "[1]and; country; dominion; district" and "Property" as a "[p]ossession held in one's own right." ${ }^{28}$ Giving the text its ordinary meaning, a reader in the late eighteenth century therefore would likely have understood that Congress had the power to regulate federal land.

The key textual issue is whether the Supremacy Clause gives preemptive effect to such "[r]egulations." The Supremacy Clause provides that the "Constitution, and the [1]aws of the United States which shall be made in [p]ursuance thereof . . . shall be the supreme [1]aw of the [1] and ... any [t]hing in the Constitution or [1] aws of any [s] tate to the [c]ontrary notwithstanding." ${ }^{29}$ A plain reading of the Property Clause in light of the Supremacy Clause supports the modern doctrine. If the Supremacy Clause applies to all federal land policy, it would be supreme over any conflicting state law.

A more limited reading of the text, however, is also possible. The Enclave Clause grants Congress the power to "exercise exclusive [1]egislation" over the District of Columbia and "all [p]laces purchased by the [c]onsent of the [1] egislature of the [s] tate in which the [s]ame shall be, for the [e]rection of [f]orts, [m]agazines, [a]rsenals, dock-[y]ards, and other needful [b]uildings." ${ }^{\prime 30}$ Congress's power of "exclusive legislation" over federal enclaves ${ }^{31}$ appears to be more robust than the Property Clause's power to make "needful [r]ules and [r] egulations." 32 Anyone reading these provisions in context at the time of the founding (or today) would assume that Congress's power to exercise "exclusive Legislation" over federal enclaves was more robust than its power to make "needful Rules and Regulations" under the Property Clause. As demonstrated below, however, Congress has always exercised an unlimited and exclusive police power over the territories prior to statehood. Any limitations on federal regulatory power under the Property Clause therefore must apply only to federal land within an existing state.

Although the Property Clause does not explicitly distinguish between federal land within a territory and a state, ${ }^{33}$ such a distinction is consistent with the

27 See Gregory E. Maggs, A Concise Guide to Using Dictionaries from the Founding Era to Determine the Original Meaning of the Constitution, 82 GEO. WASH. L. REV. 358, 359 (2014).

28 Samuel Johnson, A Dictionary of the English Language in Which the Words ARE DEDUCED FROM THEIR ORIGINALS, EXPLAINED IN THEIR DIFFERENT MEANINGS, AND Authorized by the NAMES OF THE Writers in Whole Works they ARE Found (10th ed. 1792).

${ }^{29}$ U.S. CONST. art. VI, cl. 2.

${ }^{30} I d$. art. I, § 8, cl. 17.

$31 \mathrm{Id}$.

32 Id. art. IV, § 3, cl. 2.

33 In contrast, some scholars who advance a broad reading of the Property Clause contend that, because the Clause does not distinguish between "[p]roperty" within a state and "[t]erritory" outside of a state, Congress's power over federal property must be the same in scope as its power over the territories. Appel, for example, does little to distinguish state- 
text. The Clause grants Congress the power to pass only such "[r]ules and [r]egulations" that are "needful." ${ }^{44}$ The scope of the "[r]ules and [r]egulations" that are needful for a territory may be significantly more expansive than those that are needful for federal land within an existing state. The Northwest Ordinance, for example, provided for the disposition of an estate at the death of the owner, ${ }^{35}$ but such a regulation would be unnecessary after statehood due to state intestate law.

Modern doctrine on implied powers supports this more limited reading of the text. In McCulloch v. Maryland, Chief Justice Marshall explicitly equates Congress's power to pass "needful" regulations for the territories with the Necessary and Proper Clause. ${ }^{36}$ And, in NFIB v. Sebelius, Chief Justice Roberts states that the Necessary and Proper Clause does not authorize regulations that "undermine the structure of government established by the Constitution." ${ }^{37}$ In other words, he explained, laws that are "not consist[ent] with the letter and spirit of the constitution, ... are not proper [means] for carrying into Execution Congress's enumerated powers." 38

Although Congress has not yet tried to push the boundaries of its regulatory powers under the Property Clause, the Court's unlimited interpretation of the Property Clause arguably authorizes legislation that would be inconsistent with the spirit and structure of the Constitution. As the Tenth Amendment makes clear, federal power is limited so as to preserve the sovereignty of the states. ${ }^{39}$ The Enclave Clause protects state sovereignty by imposing a requirement that the states consent before Congress is empowered to displace state power over its territory. ${ }^{40}$ Allowing Congress to bypass this requirement by having preemptive authority over all federal land without state consent thus arguably undermines structural protections for state sovereignty and federalism.

Moreover, as a textual matter, because the Enclave Clause clearly authorizes federal control over land within the states, it could be argued that its requirements must be met before Congress's "regulations" have preemptive effect over state law. Several canons of construction support this more limited reading of the Property Clause. Under the canon of generalia specialibus non

ments, cases, and historical examples involving property within a state from territories. See Appel, supra note 7 at 65 .

${ }^{34}$ U.S. CONST. art. IV, $\S 3$, cl. 2.

35 See Peter S. Onuf, Statehood and Union: A History of the Northwest Ordinance 63 (1987).

36 M'Culloch v. Maryland, 17 U.S. (4 Wheat.) 316, 382 (1819).

37 Nat'l Fed'n of Indep. Bus. v. Sebelius, 567 U.S. 519, 559 (2012) (internal citations and quotations omitted).

${ }^{38} I d$. (internal citations and quotations omitted).

39 U.S. CONST. amend. X.

40 The Enclave Clause is also limited to the seat of government and "needful Buildings." Despite this textual limitation, however, the Supreme Court has held that national parks can be federal enclaves. See Wilkinson, supra note 1, at 152-53. 
derogant, a specific provision prevails over a general provision. ${ }^{41}$ While the Property Clause generally applies to all federal property, including federal territory outside the states and chattels, the Enclave Clause applies more specifically to federal land within the existing states..$^{42}$ It is also a familiar canon that the text should be interpreted to give effect to every word so as to avoid surplusage. ${ }^{43}$ Because a broad reading of the Property Clause grants Congress an unlimited power to regulate federal land within the states, it renders the Enclave Clause meaningless. ${ }^{44}$ Reading the Property Clause in light of the Enclave Clause thus supports limiting Congress's power to enact preemptive "[r]egulations" to territories outside existing states.

In sum, the Property Clause, when read in context, could be read to grant Congress either: (1) an unlimited regulatory power over federal land, or (2) a more limited regulatory power that does not include the power to preempt contrary state legislation with respect to land within a state. Because the text is not dispositive, constitutional interpretation must turn to other sources, such as original intent, constitutional history, and court precedent.

\section{B. Original Intent}

Original intent also does little to clarify the meaning of the Property Clause. There is simply no record of the Founders discussing the power of Congress to regulate federal land within an existing state. In fact, the records of the Constitutional Convention contain little debate over any aspect of the Property Clause. On August 18, 1787, a proposal was referred to the committee of detail to grant Congress the powers "[ $t]$ o dispose of the unappropriated lands of

41 See William N. Eskridge, Jr. \& Philip P. Frickey, The Supreme Court 1993 Term Foreword: Law as Equilibrium, 108 HARV. L. REV. 26, 99 (1994) (collecting common canons of interpretation in an appendix).

42 See U.S. ConsT. art. I, § 8, cl. 17.

43 See, e.g., Herbert Hovenkamp, Judicial Restraint and Constitutional Federalism: The Supreme Court's Lopez and Seminole Tribe Decisions, 96 Colum. L. REv. 2213, 2235 (1996).

44 Goble rejects this argument by arguing that "[i]t is at least equally logical to read the article I clause as completely displacing state law by its own force, while the article IV clause is preemptive only to the extent that state law is inconsistent with congressional legislation." Goble, The Myth of the Classic Property Clause Doctrine, supra note 7, at 501. Although Goble's reading is logically possible, it is not a natural reading of the text. The Property and Enclave Clauses use dramatically different language, and Goble's interpretation would render the distinction almost meaningless. Under Goble's reading, Congress could use its Property Clause powers to immediately displace all state law, and it could use its Enclave powers to announce that state law will apply. Goble's distinction also does not address the obvious federalism concerns animating the requirement that the states consent to federal enclaves. Finally, the Court has never accepted this distinction, as state law that existed at the time of the cession presumptively applies even in federal enclaves, other than D.C. See Engdahl, supra note 7, at 333-35. The state may also qualify its consent to the enclave and retain jurisdiction over certain matters. See James L. Buchwalter, Construction and Application of Federal Enclave Clause (U.S. Const. Art. I, \& 8 cl. 17), 21 A.L.R. Fed. 3d Art. 6, § 2 (2017). 
the United States." ${ }^{45}$ Gouverneur Morris later proposed language that would become the modern Property Clause, which was adopted with no debate. ${ }^{46}$

Perhaps the most that can be said of the Founders' intent is that they thought the Property Clause authorized Congress to reenact the Northwest Ordinance and pass similar legislation. In Federalist 38, Madison pointed out that the Confederation Congress had created territorial governments and disposed of the federal lands "without the least colour [sic] of constitutional authority." 47 Madison, however, did not mean this as a criticism of Congress, because it "could not have done otherwise." 48 Instead, the Confederation Congress's lack of authority to pass the Northwest Ordinance was "an alarming proof of the danger resulting from a government, which does not possess regular powers commensurate to its objects[.]" ${ }^{\prime 49}$ In Federalist 7, Alexander Hamilton likewise stressed the danger posed by territorial disputes between the states without federal control over the public lands and pointed out that revenue from land sales could be used to retire the war debt. ${ }^{50}$

The framers therefore sought to facilitate the continuation of the federal land policy that had existed under the Articles of Confederation. Three relevant principles governed this policy: (1) the federal government would have an unlimited regulatory power over the federal territories (outside the borders of any state), (2) the new states would be equal in sovereignty to the old, and (3) the United States would retain land within the new western states.

First, the federal government would have absolute regulatory power over the territories. Unorganized settlement of the western territories could provoke conflict with Native Americans, isolate western communities, and undermine the value of prime lands that could be sold to pay down the national debt. ${ }^{51}$ As Madison also noted in The Federalist, "[t] $]$ he Confederation Congress therefore passed several ordinances regulating the territories, even though it lacked any authority to do so in the Articles of Confederation." 52 The Northwest Ordinance, for example, both provided a plan for government of the territories and directly legislated on matters such as contract rights, civil liberties, and slavery. ${ }^{53}$

452 The Records of the Federal Convention of 1787321 (Max Farrand ed., 1911).

46 Id. at 466.

47 The Federalist No. 38, at 193 (James Madison) (George W. Carey \& James McClellan eds., 2001).

${ }^{48} I d$.

49 Id.

50 The Federalist No. 7, at 26 (Alexander Hamilton) (George W. Carey \& James McClellan eds., 2001).

51 See Andrew R.L. Cayton, Radicals in the "Western World": The Federalist Conquest of Trans-Appalachian North America, in FeDERALISTS RECONSIDERED 77, 81-82 (Doron BenAtar \& Barbara B. Oberg eds., 1998); FELLER, supra note 12, at 6.

52 The Federalist No. 38, supra note 47. For a more complete discussion, see Schmitt, supra note 7, at 467-69.

53 ONUF, supra note 35 , at 49, 62-64. 
The second organizing principle of Confederation land policy was that any new states created from the territories would be equal to the original in terms of sovereignty. Through charters and land grants, the British Crown had granted Massachusetts, Connecticut, New York, Virginia, North and South Carolina, and Georgia territory extending to the Pacific Ocean. ${ }^{54}$ To encourage cessions from the states, Congress passed a resolution in 1780 providing that any territory ceded to the federal government would "be settled and formed into distinct republican states" that would "become members of the federal union" with "the same rights of sovereignty, freedom and independence, as the [original] states." $"$ Soon afterwards, Virginia, which had the most significant western land claims, passed an act of cession in $1781 .{ }^{56}$ Like Congress's 1780 resolution, Virginia's act of cession provided that the new states formed from the territory must have the same "rights of sovereignty, freedom and independence, as the other states." ${ }^{57}$ By accepting Virginia's cession in 1784, Congress again promised that the new states would be created on terms of equality. ${ }^{58}$

Later legislation reaffirmed the Confederation Congress's commitment to equal state sovereignty. The Ordinance of 1784, which was designed by Thomas Jefferson, established a system to organize the new territories and promised each new state an equal place in the Union..$^{59}$ The Northwest Ordinance of 1787 similarly pledged that all new states would be admitted "on an equal footing" with the existing states. ${ }^{60}$ In fact, the equality of the new states was inherent in the framers' conceptualization of the territorial system. The Northwest Ordinance was widely considered to be a charter for the territories analogous to the British charters for the original colonies. ${ }^{61}$ The leading scholar of the Ordinance, Peter Onuf, explains, "[t]his usage permitted the identification of new states with old: the American colonies in the West would recapitulate the colonial experience of the original states and then be recognized as their equals." ${ }^{\prime 62}$

A third principle that can be gleaned from the Confederation period is that the United States would retain title to federal land after statehood. The Northwest Ordinance states: "[t]he Legislatures of those districts, or new States, shall never interfere with the primary disposal of the Soil by the United States in Congress Assembled, nor with any regulations Congress may find necessary

54 James Rasband et al., Natural Resources Law And Policy 82 (2d ed. 2009).

53 See Arthur Bestor, Constitutionalism and the Settlement of the West: The Attainment of Consensus, 1754-1784, in The AMERICAN TERritorial SySTEM 13, 21 (John Porter Bloom ed., 1973) (quoting 18 Journals of THE ConTINENTAL Congress 1774-1789 915 (Wash. Gov't Printing Office 1910)).

56 Appel, supra note 7, at 21-22. By 1802, each of the landholding states had ceded its territory to the federal government. See RASBAND ET AL., supra note 54, at 84.

57 The Virginia Cession, IND. HistORICAL BOARD, https://www.in.gov/history/2898.htm [htt ps://perma.cc/5K5Q-6ADB] (last visited: Nov. 5, 2019).

${ }_{58} \mathrm{Id}$.

59 ONUF, supra note 35 , at xix.

${ }^{60} \mathrm{Id}$. at 50.

61 Id. at $\mathrm{xx}, 72$.

${ }^{62} I d$. at $\mathrm{xx}, 49-50$. 
for securing the title in such soil to the bona fide purchasers." ${ }^{93}$ The Ordinance therefore explicitly contemplated continued federal land ownership after statehood. More fundamentally, many agreed with the declaration of the Maryland legislature in 1776 that because the public lands were obtained with the "blood and treasure of the United States, such lands ought to be considered as a common stock." ${ }^{64}$ Congress's 1780 Resolution, moreover, guaranteed that any lands ceded to the United States would be "disposed of for the common benefit of the United States." ${ }^{65}$ Giving the public lands away at statehood would have been inconsistent with this commitment to use the public lands for the common benefit. ${ }^{66}$

Although the history of the Founding does not resolve the issue of Congress's regulatory power over federal land, the language of the Northwest Ordinance suggests that Congress would have a more limited role over federal land after statehood. The Ordinance prohibits the states from interfering with federal regulations "necessary[] for securing title." ${ }^{\prime 67}$ The Ordinance does not appear to contemplate that any other type of federal regulation would exist, and it certainly does not preserve Congress's power to preempt state legislation. And yet, the Ordinance makes federal title stronger than that of an ordinary landowner. Specifically, it provides that the states could not tax federal property, regulate its disposition, or otherwise interfere with federal land ownership. ${ }^{68}$ The Ordinance is thus consistent with this Article's proposed interpretation of the Property Clause - namely that Congress would have the regulatory power of an ordinary proprietor, but federal title to the land would receive special protections from state interference.

Moreover, the lack of meaningful debate over the Property Clause during ratification suggests that the anti-federalists did not see it as a source of danger to state sovereignty. According to Professor Peter Appel, a leading scholar on the Property Clause, "the antifederalists generally ignored the Property Clause and the power of the federal government over the West." ${ }^{\prime 9}$ If the antifederalists had thought that the Property Clause gave Congress the ability to retain an unlimited police power over potentially vast tracks of federally owned land within new states, however, the anti-federalists surely would have objected. ${ }^{70}$

63 Id. at 63.

64 See Blake A. Watson, Buying America From the Indians: JohnSON v. McInTOSH AND THE History OF NATIVE LAND Rights 110-16 (2012) (emphasis omitted).

65 See Bestor, supra note 55.

66 See Schmitt, supra note 7, at 517-18.

67 ONUF, supra note 35 , at 47.

${ }^{68} I d$.

69 Appel, supra note 7, at 28.

70 This argument is sometimes referred to as the curious incident of the dog that didn't bark. Charles A. Sullivan, The Curious Incident of Gross and the Significance of Congress's Failure to Bark, 90 TEX. L. REV. 157, 158 (2012) (quoting SiR ARTHUR ConAN Doyle, Silver Blaze, in The Complete Sherlock Holmes 383, 397 (1953)). 


\section{CONSTITUTIONAL History: Beyond THE FOUNDING AND COURT PRECEDENT}

Although Founding Era sources do not speak directly to the issue of Congress's regulatory authority over federal land within the states, the issue emerged repeatedly in Congress during the early nineteenth century. Because scholars have focused on the Founding and Supreme Court precedent, this historical evidence has largely gone unnoticed within the scholarship on Congress's regulatory powers under the Property Clause. ${ }^{71}$ And yet, as prominent legal historian David Currie demonstrates, "it was in the legislative and executive branches, not in the courts, that the original understanding of the Constitution was forged." 72 This history reveals a widespread belief that Congress's regulatory powers under the Property Clause were limited to those of an ordinary proprietor after statehood.

Constitutional history from beyond the founding period is an important factor in constitutional interpretation. In NLRB v. Noel Canning, for example, the Court explained that it "has treated [historical] practice as an important interpretive factor even when the nature or longevity of that practice is subject to dispute, and even when that practice began after the founding era." 73 According to Justice Scalia, post-ratification history is "a critical tool of constitutional interpretation" because it provides strong evidence of original public meaning. ${ }^{74}$ Historical practices can also be important to originalist theories of construction when the original public meaning of the text does not provide a concrete answer. ${ }^{75}$ Moreover, scholars who believe in a living constitution typically look to "ground[] constitutional interpretation in all of our constitutional history, rather than in the history of the Founding alone."76

71 See supra text accompanying note 7. Of course, historians have discussed these debates at length in other contexts. See, e.g., VAN ATTA, supra note 12, at 17-18.

72 David P. Currie, The Constitution in Congress: the JefFersonians 1801-1829 xi (2001). Currie's exhaustive treatment of the Constitution in Congress includes a chapter on the public lands that covers many of the same issues discussed in this Article. See id. at 9091.

73 Nat'l Labor Relations Bd. v. Canning, 573 U.S. 513, 525 (2014).

74 District of Columbia v. Heller, 554 U.S. 570, 605 (2008) (relying on nineteenth-century history to determine the original public meaning of the Second Amendment).

75 The Founders believed that, when the text was unclear, deliberate actions from Congress or the judiciary would "settle" or "liquidate" constitutional meaning and thus provide a "permanent exposition of the constitution." See Caleb Nelson, Originalism and Interpretive Conventions, 70 U. CHI. L. REV. 519, 527 (2003) (quoting James Madison).

76 See Barry Friedman \& Scott B. Smith, The Sedimentary Constitution, 147 U. PA. L. ReV. 1, 7 (1998); see also Larry Kramer, Fidelity to History — And Through it, 65 ForDHAM L. REV. 1627, 1638 (1997) ("the history that matters is not confined to the Founding, or to specific Founding moments"); David A. Strauss, Common Law Constitutional Interpretation, 63 U. CHI. L. REV. 877, 891 (1996) ("the Constitution should be followed [in part] because its provisions reflect judgments that have been accepted by many generations in a variety of circumstances"). 


\section{A. Tennessee}

Tennessee was the first state to emerge from the territories of the United States. ${ }^{77}$ Congress admitted Tennessee to the Union in 1796 with the understanding that the United States would retain title to all unappropriated federal lands. ${ }^{78}$ That same year, in a letter to Andrew Jackson, who was serving in Congress, Tennessee Governor John Sevier argued that the United States' right to the vacant lands had ended with Tennessee's statehood..$^{79} \mathrm{He}$ asserted that, if the United States were to retain title, "we should not equally stand possessed of those free and independent rights the original States enjoy." 80 When Jackson wrote back to Sevier, he agreed that continued federal landownership was inconsistent with state equality because "the right to the Soil in my oppinion [sic] is so firmly invested in the sovereignty of the State." ${ }^{81}$

Congress appointed a committee to investigate Tennessee's land claims. ${ }^{82}$ Its report, which was written in 1800 , is a remarkably clear exposition of the central thesis of this Article - although the United States retains title to the public lands, its regulatory power is ceded to the states upon admission to the Union. The report distinguishes "the right of soil," which is recognized as title to the land, and "jurisdiction," which is the power to regulate. ${ }^{83}$ The report explains that, upon admission to the Union, "Tennessee acquired the jurisdiction over, but not the right of soil, within the said territory." ${ }^{84}$ The report then states:

And this is the more satisfactorily evinced to the committee, from the consideration, that the Government of the United States held only a limited and temporary jurisdiction over the said territory, determinable on an event foreseen and specified; which the Government of the United States could not control; and upon which, the inhabitants and territory were to become an independent State or States of the Union....

There is, therefore, no ground for the claim of Tennessee to the soil, upon the principle that a grant of the jurisdiction over [the] territory possesses the right of soil therein; because, in fact, there is no grant of jurisdiction from the

77 See Ablavsky, supra note 7, at 666.

78 See id. Andrew Jackson, then a delegate to the Tennessee Constitutional Convention, and others argued that the new state should be given title to all land within its borders. Congress, however, rebuffed this argument, and it was dropped by the convention in its attempt to gain admission. Id. at 667.

79 Letter from John Sevier to Andrew Jackson (Dec. 12, 1796), in 1 THE PAPERS OF ANDREW JACKSON 102 (Sam B. Smith \& Harriet Chappell Owsley eds., 1980).

$80 \mathrm{Id}$.

81 Letter from Andrew Jackson to John Sevier (Jan. 18, 1797), in 1 THE PAPERS OF ANDREW JACKSON 117 (Sam B. Smith \& Harriet Chappell Owsley eds., 1980). Governor Sevier and the Tennessee legislature also used this constitutional argument to justify claims to Cherokee land that were guaranteed by federal law. Ablavsky, supra note 7, at 668 .

82 See Ablavsky, supra note 7, at 669.

83 See id. at 641.

841 1st Cong.-23rd Cong., American State Papers: Documents, Legislative and Executive, of the Congress of the United States in Relation to the Public Lands 98 (Walter Lowrie ed., 1834). 
United States to the State of Tennessee.But the right of jurisdiction, and the right of soil, are distinct rights, and may be severed

.... And it became a duty in the United States, by virtue of the same deed, to exercise jurisdiction over the territory until it grew into a State. The United States did exercise jurisdiction accordingly, until that event took place; upon which, that duty ceased, and the jurisdiction was of right necessarily in the State; but the right of soil remained in the United States. . . 85

When the issue first arose in 1800, therefore, Congress articulated a limited interpretation of its regulatory power under the Property Clause. ${ }^{86}$

\section{B. The Enabling Acts and Missouri Crisis}

Although the issue then lay dormant for the next several decades, the enabling acts of the new states were fully consistent with a limited view of federal power. Ohio's Enabling Act of 1802 set a precedent that would be followed in all new states. ${ }^{87}$ As promised in the Northwest Ordinance, the Enabling Act specified that Ohio would be admitted "on an equal footing with the original States in all respects whatever." 88 It further provided that Ohio could not violate the Northwest Ordinance, which prohibited the states from interfering with federal landownership after statehood. ${ }^{89}$ The Enabling Act also conditioned Ohio's admission on agreeing to exempt not only federal land from taxation, but also any land sold by the federal government for a period of five years from the date of sale. ${ }^{90}$ This provision was included at the insistence of Treasury Secretary Albert Gallatin, who was concerned that state taxation could make federal land less marketable to out-of-state purchasers. ${ }^{91}$ The enabling acts of the new states thus explicitly protected federal title from any state interference; however, they did nothing to preserve federal regulatory power.

The explosive congressional debates over Missouri's admission to the Union are also revealing. In 1819, Representative James Tallmadge of New York proposed legislation that would have admitted Missouri only on the condition

85 Id. (emphasis added).

${ }^{86}$ In 1806, Congress accommodated Tennessee's demands for the public lands by ceding title to land in the east while retaining land in the western portion of the state. See Ablavsky, supra note 7, at 669-70. Congress then ceded most of this remaining federal land to the state in 1841. See id. at 670 .

87 See Gerald L. Gutek, An Historical Introduction to American Education 173 (3d ed. 1970).

88 See Paul W. Gates, History of Public Land Law Development 285, 289 (1968).

89 Id. at 288.

90 Id. at 292. In exchange, Congress granted lands to Ohio and revenue from land sales for internal improvements. Id.

91 See Letter from Albert Gallatin to William B. Giles (Feb. 13, 1802), in 1 ThE Writings of Albert Gallatin 76 (Henry Adams ed., Antiquarian Press 1960) (1879); John LaURitz Larson, Internal Improvement: National Public Works and the Promise of Popular GOVERNMENT IN THE EARLy UNITED STATES 54 (2001). 
that it ban slavery. ${ }^{92}$ In a series of debates that threatened to tear the Union apart, Northerners insisted that Congress had plenary power to impose conditions on the admission of new states, while Southerners replied that no such conditions could undermine the equal sovereignty of the states. ${ }^{93}$ According to historian John Van Atta, prominent southerners like Henry Clay of Kentucky, the Speaker of the House, "believed that republicanism in America required that all members of the Union stand on an equal footing, no state intrinsically inferior to another. In that sense, Clay like other southerners regarded selfgovernment, not slavery, as the fundamental issue in the Missouri debate." 94

With disunion looming as a realistic possibility, Congress eventually admitted Missouri as a state without any restrictions on its sovereignty. ${ }^{95}$ In exchange for what practically amounted to the admission of Missouri as a slave state, Congress also admitted Maine, which would become a free state. ${ }^{96}$ Congress thus accepted the southern argument for equal sovereignty within the new states, though it banned slavery within the federal territories north of Missouri's southern border. ${ }^{97}$

After Congress passed the Compromise, Missouri proposed a constitution that made it illegal for the state legislature to free any slave and required the state to enact legislation to prevent free blacks from entering the state. ${ }^{98}$ The proposal arguably violated the Privileges and Immunities Clause of Article IV, as several northern states conferred citizenship on African Americans. ${ }^{99}$ James Madison wrote to President Monroe that "[t]here can be no doubt that the clause, if agst. [sic] the Constitution of the U.S. would be a nullity; it being impossible for Congress ... to vary the political equality of the States" by admitting a state on unequal terms. ${ }^{100}$ Congress ultimately admitted Missouri on "equal terms" with the original states but also explicitly prohibited the state from enacting legislation that would violate the Privileges and Immunities Clause. ${ }^{101}$ Although the Property Clause was not central to the Missouri Crisis, ${ }^{102}$ it reveals both that the equal sovereignty principle was widely thought to

92 Technically, it would have prohibited the entry of additional slaves and required the Missouri legislature to pass an act for the gradual emancipation of all slaves within the state. See John Van Atta, Wolf By the Ears: The Missouri CRISIS, 1819-1821 1 (2015).

93 Id.

94 Id. at 96.

95 Id. at 99.

${ }^{96} \mathrm{Id}$.

97 Id.

98 Id. at 116.

99 Id.

${ }^{100}$ Letter from James Madison to James Monroe (Nov. 19, 1820), (on file with FoundERS OnLINE, NAT'L ARCHIVES \& RECORDS ADMIN.), https://founders.archives.gov/documents/ Madison/04-02-02-0132 [https://perma.cc/ZQ64-8JY3].

101 VAN ATTA, supra note 92, at 120.

102 Aside from antislavery extremists, there was a general consensus that Missouri, like all previous states, would be admitted on an equal footing. Id. at 88 . The constitutional debate was about whether Congress's power to admit new states included a power to impose condi- 
constrain congressional power and that Congress had complete regulatory authority within the territories. ${ }^{103}$

\section{Western Demands for Cession}

Congress again explicitly debated its Property Clause powers in a series of high-profile debates over the public lands from 1828 to $1837 .{ }^{104}$ By the late 1820 s, federal authorities had put millions of acres of land within the new states up for sale. ${ }^{105}$ With a minimum price of $\$ 1.25$ per acre, however, supply far exceeded demand. ${ }^{106}$ When Congress rebuffed efforts from congressmen like Missouri's Thomas Hart Benton to gradually reduce the price of unsold land the longer it remained on the market (a policy known as "graduation"), frustrated and impatient westerners resurrected the constitutional argument for ceding the public lands to the states. ${ }^{107}$

During 1828, the legislatures of Illinois, Indiana, and Louisiana petitioned Congress to cede the public lands within their borders to the state governments. ${ }^{108}$ The Indiana petition, for example, asserted that the state "has the exclusive right to the soil and eminent domain of all the unappropriated lands within her acknowledged boundaries[.]"109 Like Tennessee's earlier claims, western demands for the public lands were based on the doctrine of equal state sovereignty. Senator William Hendricks of Indiana, for example, argued that "the equality and sovereignty of the new States require that these States should have the control of the public lands within their limits...."110 Senator John McKinley of Alabama, who would later serve as an associate justice on the Supreme Court, similarly contended "that the United States cannot hold land in any State of the Union, except for the purposes enumerated in the Constitution; and whatever right they had to the soil while the country remained under terri-

tions prior to admission. The Property Clause was mentioned only to contrast Congress's power over territories with that over the states. See The Right of Congress to Restrict Slavery, Mo. InTELligencer (Franklin, Missouri), Feb. 18, 1820 (arguing that the Property Clause could not justify the ban on slavery in Missouri because, after statehood, it "only gives Congress the same power over the property of the United States which every individual has over his own."); VAN ATTA, supra note 92, at 82-83 (summarizing the argument of Missourian Nathaniel Beverly Tucker).

103 Van Atta summarizes the Compromise as follows: "[e]ach section received a vital concession: the North, ample room . . . for free-labor expansion; the South and West, the right of new states to determine their own economic future with very limited congressional interference." VAN ATTA, supra note 92, at 4.

104 See infra Section II.C.

105 Aristide R. Zolberg, A Nation by Design: Immigration Policy in the Fashioning of AMERICA 131 (2006).

106 Id. at 118 .

107 See Schmitt, supra note 7, at 473-74.

1085 20th Cong., American State PaPers: Documents of the CONGREsS OF THe United States in Relation to the Public Lands 622, 624, 630 (Asbury Dickins \& John W. Forney eds., Washington, Gales \& Seaton 1860).

109 Id. at 630.

1104 REg. Deb. 152 (1828). 
torial governments, passed to the States formed over the same territory on their admission into the Union, on an equal footing with the old States." 111 The states had a right to the lands upon admission, McKinley argued, because "sovereignty is necessarily and inseparably connected with the territory and right of soil." 112 These prominent western politicians forcefully argued that the new states could not be equal in sovereignty as long as the United States retained title to the public lands. ${ }^{113}$

A close examination of the western argument, however, reveals that its proponents did not understand Congress to have an unlimited regulatory power over federal land within the states. western leaders like McKinley and Hendricks complained that federal ownership of the lands displaced state sovereignty. More specifically, McKinley complained that the new states were unequal because "they have been deprived of the right of disposing of, or in any manner interfering with the disposition of the public land, or any regulations that Congress may choose to make for securing to the purchasers any title it [may] choose to grant; [and] they have been deprived of the right of taxing the lands belonging to the United States[.]" ${ }^{114}$ McKinley thus complained only that federal title displaced state power to sell and tax the land. If he and other westerners had thought that Congress also had an unlimited regulatory power over federal land within the states, they almost certainly would have said so. Instead, McKinley complained only that Congress could regulate "for securing to the purchasers any title it [may] choose to grant." 115

As I have detailed elsewhere, Congress overwhelmingly rejected the western argument for the public lands. ${ }^{116}$ The leading statesmen from each political party and section (including many westerners) argued that the new states had no right to own the public lands within their borders. Because the United States had owned land within the new states since the time of Tennessee's admission to the Union in 1796, James Madison, the father of the Constitution, asserted that "the title in the people of the United States rests on a foundation too just and solid to be shaken by any technical or metaphysical arguments whatever." 117 Many also opposed giving the public lands to the states because a central

111 Id. at 508.

112 Id. at 509.

113 Ninian Edwards, the Governor of Illinois and a former U.S. senator, offered perhaps the most complete argument against U.S. landholding in two addresses to the Illinois legislature. See Ninian W. EDWARdS, History OF IllinOIS, From 1778 to 1833 AND

LifE AND Times of Ninian Edwards 112-13 (Arno Press 1975) (1870); Ninian Edwards, Governor of Ill., An Address to Both Houses of the Legislature (Dec. 7, 1830), at 12, in ILL. INTELLIGENCER (Vandalia, Robert Blackwell 1830); Schmitt, supra note 7, at 474-75 (summarizing Edwards' argument).

1144 REG. DEB., supra note 110, at 509.

115 Id.

116 See Schmitt, supra note 7, at 471-91.

117 Letter from James Madison (June 28, 1831), in 4 LETTERS AND OTHER WRITINGS OF James Madison, Fourth President of the United States 187-88 (Philadelphia, J.B. Lippincott \& Co. 1865). 
authority was needed to control land sales for the good of the Union. Kentucky Senator Henry Clay, for example, argued that "[c]ollisions between the States would probably arise" from state ownership of the public lands, and a "spirit of hazardous speculation would be engendered." 118 Many further argued that giving the public lands away to the citizens of the western states would violate a constitutional duty to use the land for the common benefit of the Union. ${ }^{119}$

Leading members of the nationalistic Whig Party also developed a comprehensive response to the western constitutional argument based on equal state sovereignty. Known as the National Republican Party or Adams Democrats during the $1820 \mathrm{~s}$, they favored a strong federal government that would use internal improvements, a national bank, protective tariffs, and land policy to spur development and national cohesion. ${ }^{120}$ In sum, the Whigs argued that federal landholding within the states did not violate equal state sovereignty because Congress had no more regulatory authority over such land than an ordinary proprietor. This evidence is powerful because, as more fully developed in the following section, the opposing Democratic Party was far more committed to state sovereignty and limited federal power. ${ }^{121}$

Daniel Webster, the famous "expounder of the Constitution" and leader of the Whig Party in the North, was generally a strong champion of the Union and federal power. ${ }^{122}$ In response to demands for cession of the public lands, however, he rejected the ability of Congress to preempt state regulations on federal land. He explained that "the Senate had heard much relative to the thraldom [sic] under which the new States were; of their being subjected to another legislation; of the condition of individuals who could not get a little act passed without coming to Congress." 123 The "thralldom" he referenced was the supposed power of Congress to preempt state regulatory power. However, "[h] wished to say that, so far as respects the equality of footing upon which the new States stood to the old, he saw no reason to impute inferiority." 124 This was because "[t]he [g]eneral Government exercised no legislation over the land lying in a State, except so far as that State had agreed to it. No power was now exercised by the Government over the new States which had not been exercised over the

118621 st Cong., American State Papers: Documents of the Congress of the United

States in Relation to the Public Lands 446 (Asbury Dickins \& John W. Forney eds.,

Washington, Gales \& Seaton 1860).

119 See Schmitt, supra note 7, at 517-18.

120 The National Republic Party merged with other groups in the 1830 s to form the Whig Party as a way to oppose the policies of Democratic President Andrew Jackson. See Michael F. Holt, The Rise and Fall of the American Whig Party: Jacksonian Politics AND THE ONSET OF THE CIVIL WAR 26 (2003). For the sake of simplicity, this paper will refer to this political coalition as the Whig Party.

121 See id. at 136.

122 See Robert V. Remini, Daniel Webster: The Man and His Time 162, 167 (1997); Daniel Webster, HistoRY.COM (Nov. 9, 2009), https://www.history.com/topics/19th-century /daniel-webster [https://perma.cc/UT8R-THRC].

12313 REG. DEB. 785 (1837).

124 Id. 
old." 125 In other words, Webster argued that the new states were not held in an unequal state of "thralldom" because federal landownership did not confer upon Congress the power to displace a state's legislation without its consent. ${ }^{126}$

Senator David Barton of Missouri, the chairman of the Senate Committee on Public Lands, similarly argued that federal landholding was consistent with equal state sovereignty. While the argument for cession relied on the assumption that soil and jurisdiction (i.e., landownership and regulatory power) were indivisible, Barton contended that "the answer to these new notions is, there is no such thing as absolute State sovereignty over all subjects." ${ }^{127}$ Under the Constitution, Congress had the power to own and sell the public lands, whereas the state retained the power to otherwise regulate them. ${ }^{128} \mathrm{He}$ explained: "[i]f infractions of State laws happen upon public lands within her limits, they are cognizable by State authority; and Missouri possesses all the kinds of power or sovereignty that New York does, although she has no grand canal upon which to exercise her powers." 129 According to Barton, federal landholding in Missouri was constitutional only because Missouri retained regulatory authority over the land.

Senator Henry Clay of Kentucky likewise asserted that, after statehood, Congress's powers over federal land were "[n]othing more nor less than that of a proprietor, which drew after it no legislative powers whatever." ${ }^{130} \mathrm{He}$ thus argued that, "when these States were erected, they had otherwise the same power over it as the old States. The legislative power of Congress over the territory ceased to exist." ${ }^{131}$ Like Webster, Clay was an influential leader of the Whig Party who pushed for a strong national government that could build internal improvements like roads and canals. ${ }^{132}$ His limited interpretation of Congress's Property Clause power is thus significant, as a broader interpretation could have helped to remove the constitutional doubts that plagued federal improvement projects. ${ }^{133}$

James Noble, Indiana's first U.S. senator, favored cession as a matter of policy but rejected the argument that it was constitutionally mandated. Noble

${ }^{125}$ Id. (emphasis added). Webster appears to be referring to the Enclave Clause, which grants Congress exclusive legislation but requires the consent of the states.

126 See id.

1273 Reg. Deb. 43 (1829).

128 Id.

129 Id.

13013 REG. DEB., supra note 123, at 775.

131 Id. Although Clay spoke during the debate over ceding the public lands to the states, his immediate concern in the cited speech was the land bill of 1837. The bill would have given squatters the right to purchase land at a guaranteed price if the land was for personal use, but the United States would withhold title until the buyer could prove that certain conditions were met within five years. Clay argued that such conditions were unconstitutional because "what right had Congress to legislate on the law of contracts within the bosom of the States?" Id.

132 See VAN ATTA, supra note 92, at 92-93.

133 For more on the constitutional doubts regarding internal improvements, see generally LARSON, supra note 91. 
argued that "the soil and taxation are separable from the sovereignty" of a state. ${ }^{134} \mathrm{He}$ explained that "[t]he right of domain or estate may be owned by others, within the limits of a State-possessing sovereignty, where that sovereignty cannot tax the soil." ${ }^{135}$ Noble thus argued that federal title, which differed from private title because the land could not be taxed or seized by eminent domain, was fully consistent with state sovereignty over the land. If "the rights of soil and taxation are inseparable from the sovereignty of every independent State," he argued, then Virginia's act of cession, the Northwest Ordinance, and the U.S. Constitution "are frauds" because each preserved federal title and was committed to equal state sovereignty. ${ }^{136}$ Noble further asserted that " $[\mathrm{t}]$ he moment Indiana, or any other new State, was admitted into this Union, the State possessed sovereignty[,] ... [and its] sovereignty was complete, upon the admission of the State into this Union." 137

While Webster, Barton, Clay, and Noble all explicitly said that Congress's Property Clause power was limited, many others agreed with the division between soil and jurisdiction that was central to their argument. A special House committee on public land policy in 1829 , for example, repeatedly noted that the original states ceded "sovereignty and soil" or "jurisdiction and soil" to the United States over the territories. ${ }^{138}$ When discussing federal land in 1829, however, the committee's report stated only that an "indisputable right of soil yet remains in the United States." 139 Such statements imply that, although Congress had the power to regulate and own land during the territorial stage, the states inherited regulatory power at statehood.

Others refuted the constitutional argument for cession by stressing that the new states had all agreed by statute to give up any right to ownership of the public lands within their borders. ${ }^{140}$ This argument assumes that, without such a voluntary agreement, the states would have inherited title and jurisdiction over the lands. As noted above, however, these acts preserved only federal title and said nothing about federal regulatory authority. Sovereignty- the political power to regulate - therefore was not voluntarily surrendered by the states.

It is worth stressing that, in these debates over cession of the public lands, both sides agreed that Congress could not use its powers to violate the principle of equal state sovereignty. When westerners argued that continued federal landownership within the new states violated the principle, Congress did not

\footnotetext{
1344 REG. DEB. 580 (1828).

135 Id.

136 Id. at $580-81$.

137 Id. at 581 .

1385 20th Cong., American State PaPers: Documents of the Congress of the United States in Relation to the Public Lands 794 (Asbury Dickins \& John W. Forney eds., Washington, Gales \& Seaton 1860).

139 Id. at 793.

140 See, e.g., Mr. Cligman of Surry, The Public Domain. Speech on his Resolutions, Introduced into the House of Commons on the Subject of the Public Lands, in 32:16 WESTERN CAROLINIAN, Jan. 9, 1836, at 1-2.
} 
reject equal sovereignty as a limit on its powers. ${ }^{141}$ Instead, congressional leaders constructed a constitutional argument to explain why federal ownership was fully consistent with equal state sovereignty. In sum, Congress defeated the constitutional argument for cession by disclaiming any sovereignty over federal land within the states.

\section{Native American Sovereignty}

At roughly the same time that westerners were demanding cession of the federal lands within their borders, Georgia and other southern states asserted authority over the Cherokee and other Native American tribes within their borders. ${ }^{142}$ Although the Property Clause was rarely invoked, many of the same constitutional arguments about the scope and nature of state sovereignty were raised in the ensuing debates. ${ }^{143}$ The constitutional crisis over tribal sovereignty thus confirms that the Jacksonian coalition shared the Whigs' limited view of federal power under the Property Clause.

Tribal sovereignty is a complicated issue, and the formal law was relatively undeveloped in the 1820s. ${ }^{144}$ In practice, however, the United States had long entered into treaties with the tribes and had largely refrained from interfering with their internal governance. ${ }^{145}$ The Treaty of Holston, signed by President Washington in 1791, pledged that the United States would protect the Cherokee Nation, guaranteed Cherokee lands within specified borders, and gave the United States "the sole and exclusive right of regulating their trade."146 In 1802, Georgia ceded its western land claims (present day Alabama and Mississippi) to the United States in exchange for a promise that the federal government would "peaceably" extinguish Indian title to lands within the state "on reasonable terms." 147 By the 1820 s, however, many tribes decided to retain their lands no matter the price offered. ${ }^{148}$ In fact, the Cherokee declared themselves to be

141 In fact, congressmen used the principle of equal sovereignty in other debates as well. See Mr. Reed of Mississippi, Judiciary Bill. In Senate-April 1826, in 1 NATCHEZ NewSPAPER AND PuB. AdVERTISER, June 13, 1826, at 1-2.

142 William G. McLoughlin, Georgia's Role in Instigating Compulsory Indian Removal, 70 GA. Hist. Q. 605, 629 (1986).

143 Id. at 606.

144 In Fletcher v. Peck, 10 U.S. 87, 146 (1810), Justice Johnson stated in a dissenting opinion that the tribes of western Georgia "retain a limited sovereignty, and the absolute proprietorship of their soil.” In Johnson v. M'Intosh, 21 U.S. (8 Wheat.) 543, 592 (1823), however, the Court ambiguously held that the United States had title to the land through the doctrine of discovery but that Native Americans had a lawful right of occupancy. For more on M'Intosh, see WATSON, supra note 64, at 318-28.

145 See Gerard N. Magliocca, Andrew Jackson and the Constitution: The Rise and FALL OF GENERATIONAL REGIMES 23 (2007).

146 Treaty of Holston art. VI, Apr. 26, 1802, Return to Revolution \& Early Republic 17781800: Individual Items, GEORGIAINFO, https:/georgiainfo.galileo.usg.edu/topics/history/art icle/revolution-early-republic-1776-1800/treaty-of-holston [https://perma.cc/Q4CB-EDDZ] (last visited Sept. 25, 2019).

1471 American State PAPERs, supra note 84, at 114 (Georgia Cession, Apr. 26, 1802).

148 See WATSON, supra note 64, at 319-20. 
an independent nation with an absolute right to soil and jurisdiction, effectively declaring that they would never dispose of their lands. ${ }^{149}$

Georgia responded by asserting jurisdiction over Cherokee lands and announcing that state law would be enforced against all members of the tribe within Georgia's borders. ${ }^{150}$ The Jackson Administration supported Georgia's claim and urged the Cherokee to move to the western territories. In a letter to the Cherokee delegation, Secretary of War John Eaton warned that the federal government could not support the Cherokee in any conflict over Georgia's assertion of jurisdiction because the "right ... of denying the exercise of sovereignty to that state within her own limits, cannot be admitted;- - It is not within the range of powers granted by the state to the general government." ${ }^{151} \mathrm{He}$ further said that "to continue where you are, within the territorial limits of an independent state can promise you nothing but interruption and disquietude." 152

President Jackson similarly supported Georgia in his first annual message. Jackson noted that Georgia was a "sovereign state" and that "Alabama was admitted into the Union on the same footing with the original States." $153 \mathrm{He}$ thus argued that " $[t]$ here is no constitutional, conventional, or legal provision which allows [Georgia and Alabama] less power over the Indians within their borders than is possessed by Maine or New York." 154 The federal government, he argued, therefore had no power to protect the Cherokee "if they remain within the limits of the States." 155

Jackson's supporters then introduced the Indian Removal Act, which set aside land in the western territories for eastern tribes and authorized the federal government to assist in the removal of any Indian who resisted the application of state law. ${ }^{156}$ Opposition to the bill was fierce. Senator Theodore Frelinghuysen, the leader of the opposition, ${ }^{157}$ argued that Congress had "the entire jurisdiction and control" over relations with Indians. ${ }^{158}$ Congress's exclusive power, he argued, derived from the Indian Commerce Clause and the power to enter into treaties, which became the supreme law of the land. ${ }^{159}$ Under the

\footnotetext{
149 See id. at 320.

150 Act No. 545 of Dec. 20, 1828, in A Compilation of the Laws of the State of GeOrgia 198 (W. Dawson co. 1831). Georgia was also motivated to act by the discovery of gold on Cherokee land. See MAGLIOCCA, supra note 145, at 22.

${ }^{151}$ Letter from John. H. Eaton, Secretary of War, to the Cherokee Delegation (Apr. 18, 1829), in 36 Niles' Weekly Register 259 (H. Niles \& Son eds. Mar. to Sept. 1829).

152 Id.

153 Andrew Jackson, President of the United States, First Annual Message (Dec.8, 1829), in 3 A Compilation of the Messages and Papers of the Presidents 1020 (James D. Richardson, ed., 1897) [hereinafter First Annual Message].

${ }_{154} I d$.

155 Id. at 1021.

156 See MAGLIOCCA, supra note 145, at 24.

157 See id. at 26.

1586 ReG. Deb. 314 (1830); see also id. at 344, 346 (similar statement by Senator Sprague).

159 Id. at $310,314$.
} 
Treaty of Holston, Frelinghuysen argued, the federal government had a duty to announce it would resist "all interference and encroachment" from Georgia. ${ }^{160}$

Even if no treaty had existed, Frelinghuysen argued, "[ $t]$ he laws of the State can have no effect upon a tribe of Indians or their lands within a State, so long as that tribe is independent and not a member of the State." ${ }^{161}$ This was so, he contended, because the tribes "hold by better title than either Georgia or the Union. They have nothing to do with State sovereignty, or United States, sovereignty. They are above and beyond both." 162 The Cherokee were "as perfectly independent of them [the states] as they are of Mexico."163 Georgia's sovereignty, Frelinghuysen thus argued, simply did not extend into Cherokee territory. ${ }^{164}$

Senator Peleg Sprague of Maine further argued that historical practice supported Cherokee sovereignty. "From the organization of the Government down to this very session of Congress," he asserted, there had been an "unbroken and invariable" practice of entering into treaties with Native Tribes as sovereign political actors. ${ }^{165}$ This history was important, he explained, because "[c]ontemporary exposition has always been deemed of great force in settling even the most difficult questions of constitutional law. Practice and precedent, too, have often been considered as decisive authority." 166 Sprague thus asserted that "[i]f authority and practice can settle any question, this is at an end." ${ }^{167} \mathrm{Be}-$ cause federal treaties were the "supreme law of the land," he concluded, Georgia's attempt to annul Cherokee sovereignty was invalid. ${ }^{168}$

John Forsyth of Georgia, among others, rose to defend the Removal Act on the Senate floor. He argued that the Cherokee were not an independent sovereign because, under his reading of the Treaty of Holston, the United States obtained sovereignty over the Cherokee people. ${ }^{169}$ In the 1802 compact with Georgia, he further asserted, the United States agreed to "cede to the State of Georgia, whatever claim, right, or title, they may have to the jurisdiction and

${ }^{160} \mathrm{Id}$. at 320. See also id. at 343-44 (similar statement by Senator Sprague).

161 Id. at 314 (quoting a congressional committee's interpretation of the treaty).

$162 I d$. at 312. He further explained that "by immemorial possession, as the original tenants of the soil, they [the Cherokee] hold a title beyond and superior to the British Crown and her colonies, and to all adverse pretentions of our confederation and subsequent Union." Id. at 311.

${ }^{163} \mathrm{Id}$. at 318 . He further explained that federal policy had always recognized that Indian rights were "not confined to the soil merely. We regarded them as nations . . . we conformed our conduct to their notions of civil policy." Id. at 312 .

${ }^{164} \mathrm{He}$ asserted that "where the Indian always has been, he enjoys an absolute right still to be, in the free exercise of his own modes of thought, government, and conduct." Id. at 311.

$165 I d$. at 349.

166 Id.

167 Id.

168 Id. at 346.

$169 I d$. at 326 . He referred specifically to the provision of the treaty granting the United States the right to regulate the Cherokee's trade. Id. 
soil" of the land within its borders. ${ }^{170}$ In sum, "[t]he United States obtained, by treaty, the power to legislate over the Cherokees, and transferred it to Georgia." $" 171 \mathrm{He}$ further argued that, because the United States had violated its agreement with Georgia by failing to extinguish Cherokee title, Georgia was justified in taking matters into its own hands. ${ }^{172}$ Forsyth thus argued that Georgia's actions were valid under federal law.

Like the Jackson Administration, Forsyth and other congressmen further argued that the federal government lacked the power to grant the Cherokee sovereignty over land within a state. ${ }^{173}$ The Constitution, he asserted, "gives to the $[\mathrm{g}]$ eneral $[\mathrm{g}]$ overnment no power ... to limit the jurisdiction or narrow the sovereignty of one of the States." 174 Even before the Founding, he argued, "[t]he States claimed as common property our Western lands, as obtained by the expenditure of common blood and common treasure." 175 The states "claimed the soil of the wild land for the Confederation; leaving the jurisdiction to the State where the land lay." ${ }^{176}$ Channeling the equal sovereignty argument, Forsyth pointed out that Georgia had "followed the example of ten States, in the exercise of jurisdiction over the Indians within their territory. All the New England States, New York, Virginia, North Carolina, South Carolina, and Maryland, escape censure for similar acts." 177

Congressman and future Supreme Court Justice James Wayne of Georgia similarly declared: "[w]e ask for no more than other States have and continue to exercise, without having their claims of jurisdiction over the Indians in their limits questioned. ..." 178 Wayne further contended that "[s]overeignty over soil is the attribute of States; and it can never be affirmed of tribes living in a savage condition." 179 The Indians, Wayne claimed, "were proprietors of what they used, so long as it was used; but not sovereigns of any part." 180 Senator Robert Adams of Mississippi likewise argued that "everyone living within the boundaries of a particular state is subject to the laws of that state. Otherwise chaos reigns." $" 181$

Supporters of the Indian Removal Act, however, acknowledged that Congress could grant independence to the tribes in the federal territories. Forsyth, for example, said that " $[t]$ he right of the United States to contract with, or legislate for, the Indians, beyond the States, is not denied; it is a necessary conse-

${ }^{170}$ Id. (quoting the Articles of Agreement and Cession, Apr. 24, 1802, in FoundERS ONLINE).

171 Id.

172 Id.

173 Id. at. 327.

174 Id. at 328.

$175 I d$. at 329.

176 Id.

177 Id.

178 Id. at 1128.

179 Id. at 1124.

180 Id.

181 MagliocCA, supra note 145, at 28 (quoting Senator Robert Adams). 
quence of the controlling power of the Government over the territories of the Union." 182 Under their view, however, the United States had far less authority over land located within a state. ${ }^{183}$ With Jackson's support, Congress passed the Indian Removal Act in 1830. ${ }^{184}$

The issue finally reached the Supreme Court in Worcester v. Georgia in 1832. The case arose when Georgia prosecuted a group of missionaries who lived with the Cherokee but refused to swear an oath to support Georgia's laws. ${ }^{185}$ The Court held that the conviction was void because Georgia's laws "interfere forcibly with the relations between the United States and the Cherokee nation, the regulation of which, according to the settled principles of our constitution, is committed exclusively to the government of the union." ${ }^{.186}$ The Court further held that "the Cherokee nation, then, is a distinct community, occupying its own territory, ... in which the laws of Georgia can have no force." 187 The Court therefore adopted the same constitutional arguments raised by Senators Frelinghuysen and Sprague in opposition to the Indian Removal Act.

Despite their victory in court, the Cherokee lost their land to the State of Georgia. Georgia did not enforce the Court's decision in Worcester. ${ }^{188}$ The Indian Removal Act and adherence to Worcester then became important issues during the election of 1832. ${ }^{189}$ Jackson's principal rival was Senator Henry Clay, who had earlier comprehensively defended U.S. landownership by disclaiming federal regulatory power. ${ }^{190}$ Clay criticized Jackson for undermining the power of the Court, violating treaties with Native Americans, and persecuting missionaries. ${ }^{191}$ However, Jackson won the Electoral College by a commanding margin of 219 to $49 .{ }^{192}$ Jackson then persuaded the governor of Georgia to pardon the missionaries to avoid further escalation. ${ }^{193}$ When conflict with Georgia and the U.S. government appeared possible, a faction of the Cherokee signed a treaty agreeing to removal. ${ }^{194}$ Although the Cherokee National Coun-

1826 REG. DeB. 336 (1830).

183 See id. ("Will he show us any treaty, made by Washington with Indians living altogether within the limits of a State?").

184 See WATSON, supra note 64, at 318.

185 Worcester v. Georgia, 31 U.S. (6 Pet.) 515, 529, 537 (1832). The Court dismissed the first challenge to Georgia's laws in Cherokee Nation v. Georgia because a majority held that the Cherokee did not qualify as a "foreign State" for purposes of jurisdiction. Cherokee Nation v. Georgia, 30 U.S. (5 Pet.) 1, 11, 54, 58 (1831).

186 Worcester, 31 U.S. at 520.

187 Id.

188 See MAGLIOCCA, supra note 145 , at 49.

189 See id. at 58.

190 Henry Clay, History.COM, https:/www.history.com/topics/us-politics/henry-clay [htt ps://perma.cc/B7ZU-AXVH] (last visited Nov. 5, 2019).

191 See MaglioccA, supra note 145, at 58.

192 Id. at 59.

193 Id. at 60. Jackson was especially concerned that enforcement of Worcester could push Georgia to join South Carolina in the ongoing nullification crisis. Id.

194 See WATSON, supra note 64, at 328. 
cil refused to approve the treaty, the federal government forced the Cherokee people and other Native Americans to remove to the West. ${ }^{195}$ Tens of thousands of Native Americans were forced from their homes, and thousands perished as a result. ${ }^{196}$

Not only did Worcester fail to protect the Cherokee, but it has never been fully accepted as precedent. As early as 1835, the Tennessee Supreme Court rejected Worcester and upheld the application of Tennessee law over Cherokee territory. ${ }^{197}$ The Tennessee Court held that Worcester was inconsistent with the Supreme Court's earlier decision in Johnson v. M'Intosh, which held that the United States possessed title to Indian lands through the doctrine of discovery and that Native tribes had only a right of occupancy. ${ }^{198}$ According to Professor Blake Watson, "Worcester was stillborn in the federal courts as well." 199 Van Buren's appointees to the Court, including John McKinley of Alabama who had earlier argued for cession, ${ }^{200}$ ignored Worcester and relied on Johnson. Worcester has never been overruled, but to this day the courts rely on the reasoning of Johnson for issues of tribal land ownership and sovereignty. ${ }^{201}$

Although the Property Clause was not explicitly discussed in the constitutional crisis over tribal sovereignty, the debates reveal that the Democratic Party embraced the same constitutional principles that the Whigs had advanced at roughly the same time in the debates over cession. Jackson and his supporters in Congress argued that the United States lacked the power to displace a state's sovereignty over the land within its borders. ${ }^{202}$ They further contended that, if the Cherokee were sovereign, Georgia would not be an equal member of the Union. ${ }^{203}$ As demonstrated above, these are the very same constitutional arguments that Whigs like Clay and Webster raised when explaining why federal landownership did not displace state sovereignty. Because Jacksonians broadly argued that the states must have sovereignty over the land within their borders, it is reasonable to presume that they thought the same with respect to land owned by the United States. Indeed, the United States held title to far more land in the new states than any Native American tribe did, so the constitutional argument for state sovereignty would seem to carry even more force with respect to federal land. In sum, the Jacksonians' constitutional arguments against tribal sovereignty implied that they had a limited view of Congress's regulatory power under the Property Clause as well.

195 Id.

196 See MAgLiocCA, supra note 145, at 73; WATSON, supra note 64, at 328.

197 See Watson, supra note 64, at 329 (discussing State v. Foreman, 16 Tenn. (8 Yer.) 256, 558-59 (Tenn. Sup. Ct. of Errors and Appeals, 1835)).

198 Johnson v. M'Intosh, 21 U.S. (8 Wheat.) 543, 588 (1823). The Court in Johnson further stated that the tribes' "rights to complete sovereignty, as independent nations, were necessarily diminished." Id. at 574.

199 See WATSON, supra note 64, at 330.

200 See Leshy supra note 7 at 535-36.

201 See WATSON, supra note 64, at 333.

202 McLoughlin, supra note 142 at 606-07, 629-30.

2036 REG. DEB. 1042 (1830). 
The Indian Removal Act further confirms that Jacksonians viewed federal power over land within the states very differently than such power over land within the territories. Secretary Eaton promised the Cherokee that " $[\mathrm{b}]$ eyond the Mississippi, your prospects will be different. There you will find no conflicting interests. The United States power, and sovereignty, uncontrolled by the high authority of state jurisdiction," he asserted, would be able to guarantee Cherokee lands and independence. ${ }^{204}$ Jackson likewise said that the United States could guarantee protection and independence only "without the limits of any State or Territory now formed." 205 Although the Property Clause was not explicitly referenced, the contrast between federal power within the states and federal power over the territories is unmistakable.

The constitutional arguments of the opposition to the Indian Removal Act were also consistent with a limited interpretation of federal power under the Property Clause. Notably, the opposition did not attack the principle of equal state sovereignty or the basic idea that the states presumptively had sovereignty over all land within their borders. This is important, because the federal government owned most of the land in new states like Alabama and Mississippi. ${ }^{206}$ If that ownership conveyed unlimited sovereignty to the federal government, then one might expect the opposition to argue that displacing state sovereignty was common and unproblematic. Instead, the opposition focused on the unique circumstances of tribal sovereignty. In sum, the opposition in Congress and the Court in Worcester both argued that the tribes were distinct political communities outside the reach of state sovereignty, that the United States had the exclusive constitutional authority to deal with the tribes, and that federal treaties recognizing tribunal sovereignty were the supreme law of the land. These arguments were fully consistent with state sovereignty over federally owned land.

Finally, it is worth noting that the Jacksonians could have invoked an expansive interpretation of the Property Clause to support the Indian Removal Act. In Johnson v. M'Intosh, the Supreme Court held that, although Native Americans had a lawful right of occupancy, the United States held title to the land through the doctrine of discovery. ${ }^{207}$ If the Jacksonians believed that federal ownership of land within Georgia conferred expansive regulatory authority on Congress, the Property Clause almost surely would have been raised.

\footnotetext{
204 Letter from John H. Eaton, supra note 151, at 259.

205 First Annual Message, supra note 151, at 458.

206 See VAN ATTA, supra note 12, at 144 (stating that, in 1830 , the United States retained title to more than 170 million acres of land in the public land states of Ohio, Indiana, Illinois, Mississippi, Alabama, Louisiana, and Missouri).

207 Johnson v. M'Intosh, 21 U.S. (8 Wheat.) 543, 592 (1823); see also WATSON, supra note 64, at 318-22.
} 


\section{Judicial Precedent: The Property Clause in the Supreme Court}

\section{A. Antebellum Cases}

Early cases on the meaning of Property Clause reflect that the Supreme Court shared Congress's understanding. Although the Court held that Congress had unlimited power with respect to the territories, the cases reveal that the justices had a much more limited view of federal power over property within the states. Scholarly argument to the contrary is unpersuasive and has ignored the larger context of the debates over the public lands in Congress.

In American Insurance v. 356 Bales of Cotton, the Court held that Congress has complete regulatory authority over the federal territories. ${ }^{208}$ The case arose when the owners of a shipment of cotton challenged the power of a court created by the territorial legislature of Florida to render a decision in a salvage case. ${ }^{209}$ In an opinion written by Chief Justice Marshall, the Court held that the territorial court was valid because Congress had authorized the territory to create such tribunals. ${ }^{210}$ In reaching this conclusion, Marshall held that Congress had "the combined powers of the general, and of a state government" over the territories. $^{211}$ This power, Marshall explained, derived from a "general right of sovereignty which exists in the government, or in virtue of that clause which enables Congress to make all needful rules and regulations, respecting the territory belonging to the United States." 212

Pollard v. Hagan, however, demonstrates that the Court had a more limited interpretation of congressional power over federal land within the states. ${ }^{213} \mathrm{Pol}$ lard arose from a dispute over land in Alabama that was situated within the tidal zone of the Mobile River. ${ }^{214}$ The plaintiff in Pollard sought to eject the defendant based on an 1836 grant of title from Congress. ${ }^{215}$ The issue in the case was thus whether Congress had the power to convey title to the land. The Court held that, although Congress had authority over the land while Alabama was a territory, ${ }^{216}$ Congress lost this power when Alabama became a state in 1819. ${ }^{217}$ The Court reasoned that, at the time of the Revolution, the sovereign power of the states included "the absolute right to all their navigable waters, and the soils

\footnotetext{
208 Am. Ins. Co. v. 356 Bales of Cotton, 26 U.S. (1 Pet.) 511, 546 (1828).

209 Id. at 541.

$210 I d$. at 546.

211 Id.

212 Id. Marshall therefore upheld a legislative grant of power from Congress to the territorial government of Florida. Id.

213 See Pollard v. Hagan, 44 U.S. (3 How.) 212, 229 (1845).

${ }^{214} \mathrm{Id}$. at 219-20.

215 Id. at 219.

216 U.S. Const. art. IV, § 3, cl. 2; Pollard, 44 U.S. (3 How.) at 222-23, 229.

217 Alabama, HistORY.COM, https://www.history.com/topics/us-states/alabama [https://per ma.cc/536N-354D] (last visited Nov. 5, 2019).
} 
under them for their own common use."218 Because Alabama inherited such sovereign power when it became a state, Congress's attempt to convey the land after Alabama's statehood was void. ${ }^{219}$

Although the technical holding of Pollard is limited to navigable waters, the Court went on to interpret Congress's regulatory powers over federal land within a state. The Court stated that, after Alabama became a state:

Nothing remained to the United States, according to the terms of the agreement, but the public lands. And, if an express stipulation had been inserted in the agreement, granting the municipal right of sovereignty and eminent domain to the United States, such stipulation would have been void and inoperative; because the United States have no constitutional capacity to exercise municipal jurisdiction, sovereignty, or eminent domain, within the limits of a state or elsewhere, except in the cases in which it is expressly granted. ${ }^{220}$

The Court further explained that a federal "municipal right of sovereignty" was "expressly granted" in federal land only under the Enclave Clause. ${ }^{221}$ The Property Clause, the Court stated, did not confer such a power of regulation after statehood. It explained:

We, therefore, think the United States hold the public lands within the new states by force of the deeds of cession, and the statutes connected with them, and not by any municipal sovereignty which it may be supposed they possess, or have reserved by compact with the new states, for that particular purpose. The provision of the Constitution above referred to shows that no such power can be exercised by the United States within a state. Such a power is not only repugnant to the Constitution, but it is inconsistent with the spirit and intention of the deeds of cession. ${ }^{222}$

Scholars who support a broad interpretation of the Property Clause correctly point out that the Court's holding in Pollard was limited to the ownership of land under navigable waters. ${ }^{223}$ The legal distinction between holding and dicta is important to a court constrained by a higher authority or stare decisis. The distinction, however, is much less important to the constitutional historian. Regardless of whether the Court's language in Pollard would technically control future cases, it stands as highly persuasive evidence of how the Court in 1845 understood the Constitution.

United States v. Gratiot, which was decided five years prior to Pollard, is fully consistent with a limited reading of the Property Clause. ${ }^{224}$ Gratiot involved a challenge to a federal act passed in 1807 that allowed the president to

218 Pollard, 44 U.S. (3 How.) at 229 (quoting Martin v. Waddell's Lessee, 41 U.S. (16 Pet.) 367, $410(1842))$.

219 Id.

220 Id. at 223 (emphasis added).

${ }^{221}$ Id. at 223-24.

222 Id. at 224 (emphasis added).

223 See Appel, supra note 7, at 35-36; Gaetke, supra note 7, at 641; Goble, The Myth of the Classic Property Clause Doctrine, supra note 7, at 503.

224 See United States v. Gratiot, 39 U.S. (14 Pet.) 526, 538 (1840). 
lease lead mines in Indiana territory for a period of up to five years. ${ }^{225}$ Before Illinois became a state, lead mines were leased to the defendant under the authority of the president. ${ }^{226}$ Not wishing to pay for the right to use the mines, the defendants argued that, because the Property Clause grants the power to "dispose of" federal property, Congress had the "power only to sell, and not to lease such lands." 227

In rejecting this argument, the Court did not hold that Congress has broad regulatory power over federal land within a state. Scholars who support a broad view of the Property Clause make much of the Court's statement that Congress's power under the Property Clause is "without limitation; and has been considered the foundation upon which the territorial governments rest." 228 Placed in context, however, the Court meant only that Congress's power was "without limitation[s]" when the lease was originally formed at a time prior to Indiana's statehood. ${ }^{229}$ The Court further explained that achieving statehood did not give Indiana any ground to "complain of any disposition or regulation of the lead mines previously made by Congress." ${ }^{230}$ Read in context, Gratiot merely stands for the following unremarkable propositions: (1) Congress has "unlimited" powers to legislate over a territory prior to statehood, (2) Congress's power over federal property includes the power to lease and is not limited to a power to sell title in fee simple absolute, and (3) statehood does not nullify a congressionally authorized disposition of federal land. These propositions are entirely consistent with Pollard's narrow reading of congressional regulatory power.

In his highly influential Commentaries on the Constitution, Justice Story likewise interpreted Congress's power over the territories more broadly than its power over federal land within a state. ${ }^{231}$ According to Story, "[i]t was doubtless with reference principally to this territory [the Northwest Territory], that the article of the constitution, now under consideration, was adopted." ${ }^{232}$ Similarly, Story asserted that the Property Clause "was obviously proper, in order to escape from the constitutional objection already stated to the power of congress over the territory ceded to the United States under the confederation." 233 While

\footnotetext{
225 Id. at 537.

$226 I d$. at 538.

227 Id.

228 Id. at 537; see also Appel, supra note 7, at 31-32; Goble, The Myth of the Classic Property Clause Doctrine, supra note 7, at 509-10.

229 Gratiot, 39 U.S. at 537-38. In stating that "there can be no apprehensions of any encroachments upon state rights," the Court stressed that "[t]he law of 1807, authorizing the leasing of the lead mines, was passed before Illinois was organized as a state." Id. at 538.

${ }^{230}$ Id. (emphasis added).

2313 Joseph Story, Commentaries on the Constitution of the United States; with a Preliminary Review of the Constitutional History of the Colonies and States, Before the Adoption of the Constitution § 1313190 (Fred B. Rotham \& Co. 1991) (1833).

232 Id.

${ }^{233}$ Id. $\S 1317$, at 193.
} 
Story stated that the Property Clause gave Congress power over the territories, he also asserted that Congress's power was an incident of sovereignty. Citing to American Insurance, he explained: "[a]s the general government possesses the right to acquire territory, either by conquest, or by treaty, it would seem to follow, as an inevitable consequence, that it possesses the power to govern, what it has so acquired." 234

With respect to federal land within a state, however, Story asserted that Congress's power was "not necessarily exclusive in all cases." 235 He explained: "[i]f the national government own[s] a fort, arsenal, hospital, or lighthouse establishment, not so ceded [under the Enclave Clause], the general jurisdiction of the state is not excluded in regard to the site; but, subject to the rightful exercise of the powers of the national government, it remains in full force." ${ }^{236}$ Taken together, these two sentences imply that, while Congress could regulate federal property within a state pursuant to its enumerated powers (the "rightful exercise of powers of the national government"), the states otherwise retain "exclusive" jurisdiction. ${ }^{237}$ Story clearly believed that Congress's power over federal property within a state would be narrower in scope than its power over the territories.

The Court reaffirmed its narrow understanding of the Property Clause in the infamous Dred Scott decision. ${ }^{238}$ Chief Justice Roger B. Taney's opinion for the Court notoriously held that African Americans could not be US citizens and that Congress lacked the power to ban slavery in the territories. ${ }^{239}$ While discussing Congress's power to make "needful [r]ules and [r]egulations," Taney wrote that "whatever construction may now be given to these words, every one, we think, must admit that they are not the words usually employed by statesmen in giving supreme power of legislation." ${ }^{240} \mathrm{He}$ continued: "[t]hey are certainly very unlike the words used in the power granted to legislate over territory which the new [US] Government might afterwards itself obtain by cession from a State" under the Enclave Clause. ${ }^{241}$ I zn fact, Taney declared, "[t]hey are not the words usually employed by statesmen, when they mean to give the powers of sovereignty." ${ }^{42}$ Instead, Taney argued that "[t]he words 'rules and regulations' are usually employed in the Constitution in speaking of some particular specified power which it means to confer on the Government,

\footnotetext{
234 Id. $\S 1318$, at $193-94$.

235 Id. $\S 1322$, at 198.

236 Id.

237 Appel suggests that Story meant that Congress retained a police power over territory within a state that could preempt otherwise applicable state law. See Appel, supra note 7, at 34. As explained above, this is not the most plausible reading of the text.

238 Dred Scott v. Sandford, 60 U.S. (19 How.) 393, 436-37 (1856).

239 For more on Dred Scott, see generally, Don E. FeHrenbacher, The Dred ScotT Case: Its SignificANCE IN AMERICAN LAW AND Politics (2001).

${ }^{240}$ Dred Scott, 60 U.S. at 436-37.

241 Id. at 437.

242 Id. at 440.
} 
and not, as we have seen, when granting general powers of legislation."243 Taney thus concluded that the Property Clause did not grant Congress a "despotic and unlimited power over persons and property." 244 Although Taney does not precisely define Congress's authority, he clearly had a limited view of federal regulatory power under the Property Clause.

Scholars of the Property Clause, however, have given little weight to Dred Scott for at least two reasons. First, because Dred Scott represents an aggressively proslavery interpretation of the Constitution, scholars appear to assume that the opinion's interpretation of the Property Clause must also be incorrect. ${ }^{245}$ Although Dred Scott deserves to be condemned for its support for slavery, the Court's narrow interpretation of the Property Clause was not responsible for its proslavery outcome. Importantly, Taney did not hold that Congress lacked regulatory authority over the territories; instead, he held that Congress's power over the territories could be implied from its power to acquire them. ${ }^{246}$ The federal ban on slavery was unconstitutional, Taney held, because it denied Southerners' property rights in slaves without due process of law. ${ }^{247}$ The Court's narrow reading of the Property Clause was thus not inherently proslavery.

Moreover, disregarding the decision because of its association with slavery would fail to seriously grapple with our country's past. Although Dred Scott is morally indefensible, prominent revisionist historians argue that its interpretation of the Constitution was consistent with white public opinion and possibly even correct under prevailing legal doctrine. ${ }^{248}$ Legal scholarship therefore should not pretend that the Court's support for slavery was an aberration; instead, it must recognize that the Court's proslavery viewpoint was part of the antebellum political and constitutional order. Simply assuming that everything in Dred Scott must be wrong would fail to take antebellum constitutional history seriously.

Second, scholars have probably ignored Dred Scott's interpretation of the Property Clause because the opinion is more commonly associated with the more outlandish argument that the Clause does not apply to any newly acquired territory. Justice Taney asserted that the Property Clause "applied only to the property which the States held in common at that time [the Founding], and has no reference whatever to any territory or other property which the new sovereignty might afterwards itself acquire." ${ }^{" 49} \mathrm{He}$ reached this conclusion by focusing on text and purpose. Because the text refers to "the territory" of the United

243 Id.

244 Id. at 439.

245 See Appel, supra note 7, at 37 ("The proponents of the narrow view of the Property Clause would not hinge their argument on such a hated decision ....").

246 Dred Scott, 60 U.S. at 448.

247 Id. at 450.

248 See Mark A. Graber, Dred SCott and the Problem of Constitutional Evil 39 (2006).

249 Dred Scott, 60 U.S. at 436. 
States, Taney argued that this proper noun must refer to specific land that was identifiable at the time of ratification. ${ }^{250}$ Moreover, Taney asserted that the purpose of the Clause was to enable Congress to protect U.S. citizens in the territories so that the land ceded from the states could be sold to pay the national debt from the Revolutionary War. ${ }^{251} \mathrm{He}$ thus concluded that the Property Clause referred only to the land considered by the framers at the time of ratification. ${ }^{252}$ Like most modern scholars, this Article does not endorse Dred Scott's narrow interpretation of the scope of the land governed by the Property Clause. ${ }^{253}$ The Court's error as to the scope of the land covered by the Property Clause, however, simply has nothing to do with the Court's interpretation of Congress's regulatory power over the land that is governed by the Clause. Rejecting the Court's interpretation of Congress's power because of an unrelated legal error elsewhere in the opinion is unwarranted.

\section{B. Reconstruction to New Deal}

Several late nineteenth century cases recognize also that Congress had a general police power over the territories. In First National Bank v. Yankton County, for example, the Court broadly defined congressional power over the territories as a "full and complete legislative authority over the people of the Territories and all the departments of the territorial governments." 254 Following the reasoning of Dred Scott, however, the Court did not tie this power to the Property Clause. ${ }^{255}$ In fact, the Court in United States v. Kagama explicitly disclaimed the Property Clause as a source of power. It stated that, rather than deriving from "the clause in the Constitution in regard to disposing of and making rules and regulations concerning the Territory and other property of the United States," the power to legislate for the territories arises "from the ownership of the country in which the Territories are, and the right of exclusive sovereignty which must exist in the National Government, and can be found nowhere else." ${ }^{256}$

$250 \mathrm{Id}$.

251 Id. at 435.

${ }^{252}$ Id. at 432. Taney, however, did not hold that Congress lacked regulatory authority over the territories. Instead, he held that Congress's power over the territories could be implied from its power to acquire them. $I d$. at 448 .

253 Although a full discussion is beyond the scope of this Article, the Court's application of text and framers' intent is far too rigid. In sum, the framers must have anticipated that the United States could acquire additional territory, and they certainly knew how to write the Clause more clearly if they had intended to limit it to specific lands. The argument from intent is also unconvincing because, even though the framers had specific lands in mind at the time of the Founding, the Constitution they created applies more broadly.

254 First Nat'l Bank v. Yankton Cty., 101 U.S. 129, 133 (1879).

255 Dred Scott, 60 U.S. at 440.

256 United States v. Kagama, 118 U.S. 375, 380 (1886) (citations omitted); see also Murphy v. Ramsey, 114 U.S. 15, 44 (1885) ("The people of the United States, as sovereign owners of the National Territories, have supreme power over them and their inhabitants."); First Nat'l Bank, 101 U.S. at 133 (referring to Congress's power over the territories as "an incident of sovereignty"). 
The Court more fully explained the basis of Congress's "general and plenary" power over the territories in Late Corporation of the Church of Jesus Christ of Latter-Day Saints v. United States. ${ }^{257}$ While upholding Congress's revocation of the charter of the Mormon Church, the Court explained that, "[h]aving rightfully acquired said territories, the United States government was the only one which could impose laws upon them, and its sovereignty over them was complete. No State of the Union had any such right of sovereignty over them; no other country or government had any such right." ${ }^{258}$ Quoting Justice Marshall in Insurance Company v. Canter, the Court continued to explain that "the power of governing a Territory belonging to the United States, which has not, by becoming a State, acquired the means of self-government, may result necessarily from the facts, that it is not within the jurisdiction of any particular State, and is within the power and jurisdiction of the United States." 259 Congress's authority, therefore, was "self-evident" from the lack of any other lawmaking body. ${ }^{260}$ Although the Court did not reach the issue of whether Congress retained such a "general and plenary" authority over federal land within a state, its reasoning would have no application after statehood. ${ }^{261}$

In fact, the Court's late eighteenth century Property Clause decisions demonstrated that the Court continued to believe that Congress had less authority over federal land within a state. In 1885, the Court in Fort Leavenworth Railroad Company v. Lowe held that the state of Kansas had the power to tax a railroad operating on the federal military installation of Fort Leavenworth. ${ }^{262}$ The Court explained that, before Kansas was admitted to the Union, "the United States possessed the rights of a proprietor, and had political dominion and sovereignty" over the land. ${ }^{263}$ However, after "Kansas was admitted into the Union upon an equal footing with the original States," the United States "retained ... only the rights of an ordinary proprietor...."264 As a result, the Court held, "[t]he State could have exercised, with reference to it, the same authority and jurisdiction which she could have exercised over similar property held by private parties." 265

${ }^{257}$ Late Corp. of the Church of Jesus Christ of Latter-Day Saints v. United States, 136 U.S. 1,42 (1890).

${ }^{258} \mathrm{Id}$. at $42-43$. The Court began its discussion by stating that Congress's power over the territories was "incidental to the right to acquire the Territory itself, and from the power given by the Constitution to make all needful rules and regulations respecting the Territory or other property belonging to the United States." Id. at 42. The Court, however, did not mention the Property Clause again, and, as explained above, its reasoning depended on the sovereignty justification. See id. at 59 .

259 Id. at 43.

$260 \mathrm{Id}$.

261 Scholars who have attempted to use precedent regarding the territories to define Congress's power over land within a state therefore miss the mark.

262 Fort Leavenworth R.R. Co. v. Lowe, 114 U.S. 525, 526, 542 (1885).

263 Id. at 526.

${ }^{264} \mathrm{Id}$. at 526-27.

265 Id. at 527. 
The Court further held that, although the tax would have been invalid if Fort Leavenworth were a federal enclave, the requirements of the Enclave Clause had not been met. ${ }^{266}$ Pursuant to the Enclave Clause, Congress has "exclusive" jurisdiction over land obtained with the consent of the state. ${ }^{267}$ The Court noted, however, that the federal government had long purchased land within the states without obtaining such state consent. ${ }^{268}$ The Court explained:

The consent of the States to the purchase of lands within them for the special purposes named is, however, essential, under the Constitution, to the transfer to the general government, with the title, of political jurisdiction and dominion. Where lands are acquired without such consent, the possession of the United States, unless political jurisdiction be ceded to them in some other way, is simply that of an ordinary proprietor. The property in that case, unless used as a means to carry out the purposes of the government, is subject to the legislative authority and control of the States equally with the property of private individuals. $^{269}$

It is difficult to square this passage with unlimited regulatory power under the Property Clause.

This is not to say, however, that the Fort Leavenworth Court held that the states have absolute power over federal land. Instead, the Court said that federal land, like all land, would be exempt from state legislation if "essential to the independence and sovereign authority of the United States within the sphere of their delegated powers." ${ }^{270}$ State law, in other words, would still be preempted if it conflicted with Congress's enumerated powers, such as its power over commerce and the post office. ${ }^{271}$

As the Court in Fort Leavenworth noted, U.S. Attorney General George H. Williams reached a similar conclusion in an official opinion in 1872. Williams wrote that, "while the United States appear to now hold the land[][,] . . . it would seem that the jurisdiction over the same has passed to the State of Kansas by virtue of the act of June 29, 1861, admitting that State into the Union."272 He further explained that " $[\mathrm{t}]$ he effect of that act was to withdraw from Federal jurisdiction all the territory within the boundaries of the new State, excepting only the territories of Indians. . .."273

In Ward v. Race Horse, the Court took Fort Leavenworth a step further and held that congressional regulations of activities on federal land were invalid if they conflicted with state legislation. ${ }^{274}$ Prior to the admission of Wyoming, the United States had entered into a treaty that guaranteed hunting rights to the

\footnotetext{
266 Id. at 542.

267 U.S. CONST. art. I, $\S 8$, cl. 17.

268 Fort Leavenworth R.R. Co., 114 U.S. at 530.

269 Id. at 531.

270 Id. at 539.

271 See Engdahl, supra note 7, at 306.

272 Fort Leavenworth Military Reservation, 14 Op. Att'y Gen. 33, 34 (1872).

273 Id. (emphasis added).

274 Ward v. Race Horse, 163 U.S. 504, 516 (1896).
} 
Bannock Indians on unoccupied federal lands within the state. ${ }^{275}$ Wyoming sought to regulate hunting on federal land and challenged the treaty by arguing that the equal footing doctrine made it the "preeminent sovereign" over federal land within its borders. ${ }^{276}$ The Court accepted Wyoming's argument and stated the following:

The power of all the States to regulate the killing of game within their borders will not be gainsaid, yet, if the treaty applies to the unoccupied land of the United States in the State of Wyoming, that State would be bereft of such power, since every isolated piece of land belonging to the United States as a private owner, so long as it continued to be unoccupied land, would be exempt in this regard from the authority of the State. Wyoming, then, will have been admitted into the Union, not as an equal member, but as one shorn of a legislative power vested in all the other States of the Union, a power resulting from the fact of statehood and incident to its plenary existence. ${ }^{277}$

The Court therefore held that Congress implicitly repealed the treaty by admitting Wyoming as a state because "the [hunting] privilege conferred and the act of admission [of Wyoming as a state], are irreconcilable in the sense that the two[,] under no reasonable hypothesis[,] can be construed as coexisting." 278 Because there would have been no conflict between the treaty and the admission of Wyoming if Congress had the power to preempt state hunting law on federal land under the Property Clause, the Court must have narrowly interpreted Congress's property power.

Scholars have rightly criticized Ward for failing to recognize that federal treaties and Indian law preempt any conflicting state law and should be liberally construed in favor of native tribes. ${ }^{279}$ In fact, Herrera $v$. Wyoming, which the Supreme Court decided just this term, explicitly rejects Race Horse's argument that the federal treaty interfered with state sovereignty. ${ }^{280}$ And yet, scholars are wrong to therefore conclude that Ward has nothing to say about how the Court understood the Property Clause in $1896 .{ }^{281}$ The Court's decision in Ward shows that the justices thought Congress had no power to preempt state law regarding hunting on federal land. ${ }^{282}$ The fact that the Court erred by holding that the

275 David E. Wilkins, Indian Treaty Rights: Sacred Entitlements or "Temporary Privileges?", 20 AM. Indian Culture \& Res. J. 87, 96 (1996).

276 Id. at 106.

277 Race Horse, 163 U.S. at 514.

278 Id.

279 See Wilkins, supra note 275, at 105. In fact, the District Court struck down the Wyoming law on the grounds that it was preempted by the federal treaty. See id. at 103-04.

${ }^{280}$ Herrera v. Wyoming, No. 17-532 8 (U.S. May 20, 2019) (holding that the treaty did not infringe on state sovereignty because "[s]tates can impose reasonable and nondiscriminatory regulations on an Indian tribe's treaty-based hunting, fishing, and gathering rights on state land when necessary for conservation."). The Court thus held that a federal treaty with the Crow Tribe granting hunting rights on federal land remained valid, even though the treaty was analogous to the treaty at issue in Race Horse. Id. at 17.

281 See Goble, The Myth of the Classic Property Clause Doctrine, supra note 7, at 505 n.44 (arguing that "[ $\mathrm{t}]$ he decision thus is inapposite because it turns upon the treaty clause ...."). 282 See Race Horse, 163 U.S. at 514. 
treaty had been implicitly repealed does not change the Court's narrow reading of the Property Clause.

Although the Court held that Congress's regulatory authority was limited, the Court also held that the federal government was not an ordinary proprietor. In Gibson v. Chouteau, the Court held that a state could not authorize a private party to take equitable title to federal land based on possession. ${ }^{283}$ The Court stated:

With respect to the public domain, the Constitution vests in Congress the power of disposition and of making all needful rules and regulations. That power is subject to no limitations. Congress has the absolute right to prescribe the times, the conditions, and the mode of transferring this property, or any part of it, and to designate the persons to whom the transfer shall be made. ${ }^{284}$

As a result, the Court held, "[n]o State legislation can interfere with this right or embarrass its exercise ...." 285 Taken in context, the Court's statement that Congress's power is "subject to no limitations" refers to Congress's power to own and dispose of property. Gibson is therefore fully consistent with limited federal regulatory power.

In 1897, however, the Court took an incremental step towards a broader view of federal power in Camfield v. United States. ${ }^{286}$ The defendant in Camfield was charged with violating a statute that made it illegal to enclose federal land. ${ }^{287}$ Due to a system of land grants that was common in the West, the defendants owned all of the odd-numbered sections of land in the area in question. ${ }^{288}$ By building a fence only on their privately-owned odd-numbered lots, the defendants managed to fence in the federally owned even-numbered lots as well. ${ }^{289}$ Because their fences were not physically located on federal land, the defendants argued that the federal act was unconstitutional as applied to them. ${ }^{290}$

The Court upheld the application of the federal act. The Court explained that "the Government has, with respect to its own lands, the rights of an ordinary proprietor to maintain its possession and to prosecute trespassers. It may deal with such lands precisely as a private individual may deal with his farming property. It may sell or withhold them from sale." 291 If the fences had been built on federal land, the Court therefore stated, the federal government could have abated the fences without recourse to state officers. ${ }^{292}$ The Court therefore took a broad view of Congress's powers as a proprietor-not only could Con-

\footnotetext{
283 Gibson v. Chouteau, 80 U.S. (13 Wall.) 92, 104 (1871).

${ }^{284}$ Id. at 99.

285 Id.

286 See Camfield v. United States, 167 U.S. 518, 528 (1897).

287 Id. at 521-22.

288 Id. at 526.

289 Id. at 522.

290 Id.

291 Id. at 524.

292 Id.
} 
gress prohibit trespassing on federal land, but it could directly punish trespassers. Unlike an ordinary landowner, the United States was not required to seek state assistance to punish a private party that interfered with its property rights.

The Camfield Court applied this broad view of Congress's proprietor power to police conduct on private land that directly interfered with Congress's property rights. The Court held: "we think the fence is clearly a nuisance, and that it is within the constitutional power of Congress to order its abatement, notwithstanding such action may involve an entry upon the lands of a private individual." ${ }^{293}$ Confusingly, the Court characterized Congress's power over federal lands within a state both as that of an "ordinary proprietor" and as "analogous to the police power of the several States." 294 The Court, however, clarified that

the extent to which it may go in the exercise of such power is measured by the exigencies of the particular case. If it be found to be necessary for the protection of the public or of intending settlers, to forbid all enclosures of public lands, the Government may do so . . . ${ }^{295}$

The Court continued to explain that it did "not think the admission of a Territory as a State deprives it of the power of legislating for the protection of the public lands, though it may thereby involve the exercise of what is ordinarily known as the police power, so long as such power is directed solely to its own protection." ${ }^{296}$ At the turn of the twentieth century, therefore, the Court held that Congress had a power to regulate activities on private land within a state when the "exigencies of the particular case" made such regulation necessary "for the protection of the public ...."297

Camfield thus held for the first time that Congress could regulate extraterritorially under the Property Clause. ${ }^{298}$ Congress, in other words, could use the Property Clause to regulate activities that did not take place on federal land. The Court's explicit connection of this power to nuisance law, however, suggests that Congress's regulatory power was quite narrow. According to the First Restatement of Torts, a nuisance is a "non-trespassory invasion of another's interest in the private use and enjoyment of land." ${ }^{299}$ An action in nuisance is thus

\footnotetext{
293 Id. at 525.

294 Id.

295 Id.

296 Id. at 525-26.

297 Id. at 525; Hunt v. United States, 278 U.S. 96, 100 (1928). In a brief two-page opinion in Hunt, the Court applied Camfield to a federal law that permitted the killing of deer on federal land in contravention of state hunting laws due to overgrazing, the federal law "was necessary to protect the lands of the United States within the reserves from serious injury." Id.

298 Modern doctrine has not clearly articulated a principle for understanding Congress's power to regulate state land under the Property Clause. For a scholarly debate over the reach of Congress's extraterritorial powers, see Allison H. Eid, The Property Clause and New Federalism, 75 U. CoLo. L. REv. 1241, 1249 (2004) (arguing for a narrow interpretation); Goble, The Myth of the Classic Property Clause Doctrine, supra note 7, at 509 (arguing for a broad interpretation).

2994 RESTATEMENT (FIRST) OF TORTS $§ 822$ (AM. LAW. INST. 1939).
} 
not a state-law tort claim like negligence; instead, it is a remedy for an invasion of a property interest. The Court in Camfield merely held that, when a private party invades federal property interests, the federal government may directly abate the nuisance without appealing to the state courts for a remedy. ${ }^{300}$ This is hardly an expansive interpretation of congressional power, as private landowners could also abate a nuisance by self-help under certain circumstances under the common law. ${ }^{301}$ Moreover, the Court's holding in Camfield is consistent with the Court's longstanding view that federal title is different than private title. Just as the Court held in Gibson that the states cannot divest the U.S. of title through adverse possession, Camfield held that the federal government may legislate to protect the U.S.'s property rights from private invasions. ${ }^{302}$

Later cases confirm that the Court's opinion in Camfield did not signal a reversal in the Court's limited reading of the Property Clause. ${ }^{303}$ In Butte City Water Company v. Baker, for example, the defendant challenged Congress's delegation to the states of the power to enact regulations regarding mining rights on federal land. ${ }^{304}$ Although the law would seem to have violated the prevailing anti-delegation doctrine, ${ }^{305}$ the Court upheld the delegation because Congress's power under the Property Clause was "not of a legislative character in the highest sense of the term ...." "306 The Court reasoned that the Property Clause granted Congress only the "power to determine the conditions upon which the public lands shall be disposed of." 307 Because "an owner may delegate to his principal agent the right to employ subordinates, giving to them a limited discretion, so it would seem that Congress might rightfully entrust to

300 See Camfield, 167 U.S. at 524.

301 See Den v. Hoboken Land \& Improvement Co., 59 U.S. (18 How.) 272, 284 (1855); Jon K. Wactor, Self-Help: A Viable Remedy for Nuisance? A Guide for the Common Man's Lawyer, 24 ARIZ. L. REV. 83, 83 (1982).

302 Other cases held the same. See Light v. United States, 220 U.S. 523, 536 (1911) (quoting United States v. Beebee, 127 U.S. 342 (1888)) ("And if it may withhold from sale and settlement it may also as an owner object to its property being used for grazing purposes, for 'the Government is charged with the duty and clothed with the power to protect the public domain from trespass and unlawful appropriation.' ").

303 See Kansas v. Colorado, 206 U.S. 46, 92 (1907) ("We do not mean that its legislation [under the Property Clause] can override state laws in respect to the general subject of reclamation."); Light, 220 U.S. at 536 (quoting Camfield, 167 U.S. at 524 ("The Government has with respect to its own lands the rights of an ordinary proprietor to maintain its possession and to prosecute trespassers. It may deal with such lands precisely as an ordinary individual may deal with his farming property.”)); United States v. Midwest Oil Co., 236 U.S. 459, 474 (1915) ("Congress not only has a legislative power over the public domain, but it also exercises the powers of a proprietor . ..."). In Light, a defendant who was prosecuted for grazing his cattle on federal land without a license argued that a state law provided a defense. The Court did not hold that federal grazing law would preempt any inconsistent state law; instead, the Court made a point to argue that the state law was inapplicable to "wanton and willfull trespass." Light, 220 U.S. at 537.

304 Butte City Water Co. v. Baker, 196 U.S. 119, 125 (1905).

305 See Appel, supra note 7, at 62; Engdahl, supra note 7, at 309.

306 Butte City Water, 196 U.S. at 126.

307 Id. 
the local legislature the determination of minor matters respecting the disposal of these lands." ${ }^{308}$ In other words, Congress's delegation was constitutional because it could only delegate a limited power to dispose of the federal land. Although the Court began expanding federal power in Camfield, the Court in Baker stressed that federal power was still limited.

In 1917, the Court in Utah Power \& Light Company v. United States stated that although Congress had the legislative power to protect federal lands, as the Court had found in Camfield, and determine property rights therein, as the Court had stated in Gibson, the state otherwise had jurisdiction over federal lands, as the Court had held in Ward. ${ }^{309}$ The defendant in Utah Power argued that, because federal land within a state could be regulated by the state in the same manner as any privately held land, it was entitled to a right of way on unoccupied federal land based on state law. ${ }^{310}$ In rejecting this contention, the Court explained:

True, for many purposes a State has civil and criminal jurisdiction over lands within its limits belonging to the United States, but this jurisdiction does not extend to any matter that is not consistent with full power in the United States to protect its lands, to control their use and to prescribe in what manner others may acquire rights in them. Thus while the State may punish public offenses, such as murder or larceny, committed on such lands, and may tax private property, such as live stock, located thereon, it may not tax the lands themselves or invest others with any right whatever in them. 311

In other words, Congress could not be divested of its property rights by state law. As the Court explained in Light v. United States, "[t]he United States can prohibit absolutely or fix the terms on which its property may be used." 312 When property rights were not at issue, however, state law would prevail. ${ }^{313}$

\section{The New Deal to Today}

In the New Deal Era, however, the Court abruptly changed course and expansively interpreted Congress's power over federal land within a state. In 1940, the Court in United States v. City and County of San Francisco broadly stated that " $[t]$ he power over the public land thus entrusted to Congress is without limitations. And it is not for the courts to say how that trust shall be administered. That is for Congress to determine." 314 The Court therefore upheld conditions imposed by Congress on a grant of federal land to San Francisco that prohibited the City from allowing a private company to use the land for the purpose of selling water or electricity. ${ }^{315}$ The Court explained that Congress's

308 Id.

${ }^{309}$ Utah P ower \& Light Co. v. United States, 243 U.S. 389, 392, 405 (1917).

310 Id. at 403.

311 Id. at 404 (citations omitted).

312 Light v. United States, 220 U.S. 523, 536 (1911).

313 Id.

314 United States v. City \& Cty. of S.F., 310 U.S. 16, 29-30 (1940).

315 Id. at 19-20. 
conditions did "not represent an exercise of a general control over public policy in a State but instead only an exercise of the complete power which Congress has over particular public property entrusted to it." 316 The Court thus broadly declared that Congress's power over federal lands was "complete," "without limitations," and could be used to achieve Congress's "views of public policy." 317 Soon after the New Deal Court began deferring to Congress in its Commerce Clause jurisprudence, the Court stated that "it is not for the courts to say how that trust [the power entrusted to Congress under the Property Clause] shall be administered." 318

The Court cemented its expansive interpretation of congressional power in the seminal case of Kleppe $v$. New Mexico. ${ }^{319}$ This case involved a challenge to the constitutionality of the federal Wild Free-roaming Horses and Burros Act, which protected wild horses and burros on federal land. ${ }^{320} \mathrm{~A}$ rancher complained to state authorities that wild burros were eating his feed and harassing his livestock that were legally grazing on federal land. ${ }^{321}$ The state authorities rounded up the burros on federal land and sold them at public auction pursuant to the New Mexico Estray Law. ${ }^{322}$ After the sale, the federal Bureau of Land Management demanded that the state recover the animals. ${ }^{323}$ New Mexico then filed suit seeking a declaratory judgement that the Wild Free-roaming Horses and Burros Act was unconstitutional. ${ }^{324}$

The Kleppe Court held that "the Property Clause ... gives Congress the power to protect wildlife on the public lands, state law notwithstanding." 325 In doing so, the Court rejected the state's argument that the Property Clause granted Congress only: "(1) the power to dispose of and make incidental rules regarding the use of federal property; and (2) the power to protect federal property." ${ }^{26}$ Instead, the Court held, "Congress exercises the powers both of a proprietor and of a legislature over the public domain," and its power over federal property is "without limitation[]." ${ }^{327}$ Congress had found that wild burros were "an integral part of the natural system of the public lands," and the Court did not question this conclusion because "determinations under the Property Clause are entrusted primarily to the judgment of Congress." 328 Kleppe's broad interpretation of the Property Clause remains good law today.

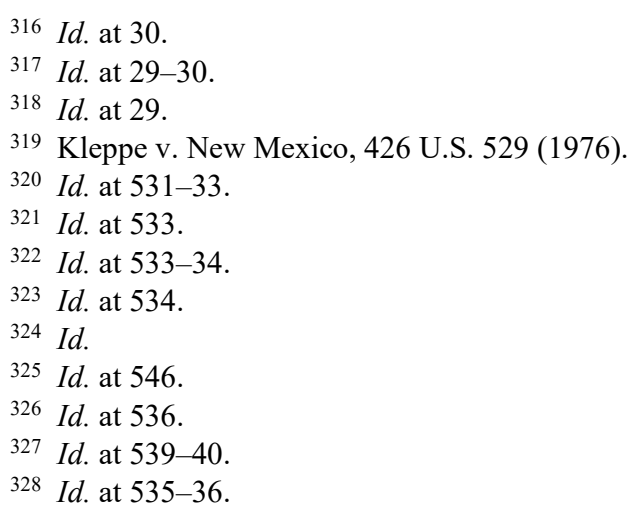


In California Coastal Commission v. Granite Rock, the Court held that while Congress's power over federal land is unlimited, it is not exclusive. ${ }^{329}$ The plaintiff in Granite Rock challenged a California law that required it to obtain a permit before mining on federal land under the federal Mining Act. ${ }^{330}$ The Court held that "the State is free to enforce its criminal and civil laws on federal land so long as those laws do not conflict with federal law." 331 The Court thus announced that Congress's "plenary power" over the federal lands was not exclusive, but that any state regulation of activities on federal land would be subject to ordinary preemption analysis. ${ }^{332}$

\section{Structure: The Property Clause AND Federalism}

\section{A. New Federalism}

Kleppe's expansive interpretation of congressional power over the public domain is inconsistent with the Court's modern federalism jurisprudence. Using "a form of structural inference," the Court in these cases has developed "implied limitations in federal power that are traceable to some form of historically reconstructed original understanding of the appropriate federal-state balance." ${ }^{\prime 33}$ In these cases, the Court has sought to limit the potentially unbounded power granted to Congress during the New Deal. ${ }^{334}$

The Court's Commerce Clause jurisprudence provides an apt analogy. In the decades leading up to the New Deal, the Court narrowly defined commerce and did not allow Congress to intrude on a zone of activities reserved to the states. ${ }^{335}$ In Hammer v. Dagenhart, for example, the Court struck down a regulation of goods produced by child labor because, "[t]he power of the States to regulate their purely internal affairs by such laws as seem wise to the local authority is inherent and has never been surrendered to the general government." "336 After 1936, however, the Supreme Court changed course and upheld

329 California Coastal Comm'n v. Granite Rock Co., 480 U.S. 572, 575 (1987).

$330 \mathrm{Id}$.

331 Id. at 580 (citing Kleppe, 426 U.S. at 543).

$332 I d$. at 581 .

333 John F. Manning, Federalism and the Generality Problem in Constitutional Interpretation, 122 HARv. L. Rev. 2003, 2006, 2024-25 (2009); see also Roderick M. Hills, Jr., The Political Economy of Cooperative Federalism: Why State Autonomy Makes Sense and "Dual Sovereignty" Doesn't, 96 Mich. L. REv. 813, 831 (1998); Ernest A. Young, Alden v. Maine and the Jurisprudence of Structure, 41 WM. \& MARY L. REV. 1601, 1620 (2000).

${ }_{334}$ See Manning, supra note 333, at 2053-54; H. Geoffrey Moulton, Jr., The Quixotic Search for a Judicially Enforceable Federalism, 83 MinN. L. REV. 849, 894 (1999); Ernest A. Young, Making Federalism Doctrine: Fidelity, Institutional Competence, and Compensating Adjustments, 46 WM. \& MARY L. REV. 1733, 1757-58 (2005).

335 See, e.g., Grant S. Nelson \& Robert J. Pushaw, Jr., Rethinking the Commerce Clause: Applying First Principles to Uphold Federal Commercial Regulations but Preserve State Control over Social Issues, 85 IowA L. REV. 1, 68-69 (1999).

336 Hammer v. Dagenhart, 247 U.S. 251, 275 (1918), overruled by United States v. Darby, 312 U.S. 100, 116-17 (1941). 
the New Deal's vast expansion of federal power. ${ }^{337}$ While upholding the Fair Labor Standards Act in United Stated v. Darby, for example, the Court stated that " $[t]$ he power of Congress over interstate commerce "is complete in itself, may be exercised to its utmost extent," "and "can neither be enlarged nor diminished by the exercise or non-exercise of state power." 338 In cases like Wickard v. Filburn, the Court further held that the Commerce Clause empowered Congress to regulate purely local activities so long as such activities, in the aggregate, have a substantial economic effect on interstate commerce. ${ }^{339}$ Because virtually everything has an economic effect, the New Deal interpretation of the Commerce Clause effectively gave Congress an unlimited police power over the nation. ${ }^{340}$ The New Deal Court's expansive view of federal commerce power mirrors Kleppe's unlimited Property Clause.

Starting with United States v. Lopez in 1995, however, the Court has imposed significant limitations on Congress's commerce power. ${ }^{341}$ The Court in United States v. Lopez rejected the idea that Congress could regulate any activity that had an economic effect. ${ }^{342}$ Instead, the Court held that Congress could use the Commerce Clause to regulate only activities that were themselves economic in nature. ${ }^{343}$ The Court then applied this doctrinal limitation to strike down the Gun-Free School Zones Act after finding that the mere possession of a handgun is a noneconomic activity. ${ }^{344}$ In United States v. Morrison, the Court similarly struck down the Violence Against Women Act after finding that gender-motivated violence is not economic activity, notwithstanding the uncontested fact that such violence substantially affects the interstate economy. ${ }^{345}$ The Court further limited Congress's power under the Commerce Clause in $\mathrm{Na}$ tional Federation of Independent Business v. Sebelius by holding that Congress can only regulate preexisting commercial activity and cannot "create" commerce. $^{346}$

The Court explicitly tied these doctrinal limitations to federalism concerns. ${ }^{347}$ The Court in Lopez, for example, warned that a broad interpretation of the commerce power would eliminate any "limitation on federal power, even in areas ... where States historically have been sovereign." ${ }^{348}$ And, in N.F.I.B.,

337 The reasons for the Court's "switch in time" are beyond the scope of this Article. For more on this issue, see, e.g., Barry Cushman, Rethinking the New Deal Court: The StRUCTURE OF A CONSTITUTIONAL REVOLUTION 3 (1998).

338 United States v. Darby, 312 U.S. 100, 114 (1941) (citations omitted).

339 Wickard v. Filburn, 317 U.S. 111, 125 (1942).

340 See, e.g., Nelson \& Pushaw, supra note 335, at 82-83.

341 See United States v. Lopez, 514 U.S. 549, 567-68 (1995).

${ }^{342} I d$. at 564, 566-68.

343 Id. at 560. The Court further held that Congress could regulate the channels, instrumentalities, or persons or things in interstate commerce. $I d$. at 558-59.

344 Id. at 567.

345 United States v. Morrison, 529 U.S. 598, 614 (2000).

346 See Nat'l Fed'n of Indep. Bus. v. Sebelius, 567 U.S. 519, 550, 552, 588 (2012).

347 Id. at 577-78; Lopez, 514 U.S. at 564-66.

348 Lopez, 514 U.S. at 564. 
the Court rejected a broad interpretation of Congress's powers that "would carry us from the notion of a government of limited powers." "349 As the Court stated in both cases, "we should 'pause to consider the implications' ... when confronted with such new conceptions of federal power." ${ }^{350}$ Indeed, Justice Roberts stated in N.F.I.B. that even the Necessary and Proper Clause could not save those laws "that undermine the structure of government established by the Constitution." 351

Like with the Commerce Clause, Congress could use a broad reading of its power under the Property Clause to eviscerate federalism. At its core, federalism is a system of government that empowers the states to disagree with federal decisions on important matters of policy ${ }^{352}$ Constitutional protections for federalism are thus meaningful only if they preserve some measure of state independence on public policy. As illustrated in this Article's introduction, however, the Court's reading of the Property Clause would empower the federal government to effectively overrule state law on important policy matters that are traditionally left to the states. On many important issues that have become cultural flashpoints, such as abortion, immigrant detention, physician-assisted suicide, gambling, and drug use, a broad reading of the Property Clause would allow Congress to frustrate state policy. For example, Congress could authorize the construction of abortion clinics, casinos, marijuana dispensaries, or hospice centers that practice assisted suicide on federal land. Such a power would be especially significant given the fact that Congress can purchase or take additional land under its eminent domain power. The Court's broad interpretation of the Property Clause therefore has the potential to undermine the Court's federalism revolution by empowering Congress to overrule important state policy. As the Court stated in Morrison, "[u]nder our written Constitution, . . . the limitation of congressional authority is not solely a matter of legislative grace." 353

The Court's broad interpretation of the Property Clause is even more problematic when applied beyond the metes and bounds of federal land. ${ }^{354}$ The Court's holding in Camfield - that Congress can abate a nuisance on privately owned land that interferes with the use and enjoyment of federal land-seems unobjectionable. A sufficiently broad interpretation of the Property Clause, however, would essentially create an unlimited federal police power. Because natural ecosystems are highly interconnected, virtually any land use or activity that causes pollution could substantially affect federal land. ${ }^{355}$ Moreover, most

\footnotetext{
349 Nat'l Fed'n of Indep. Bus., 567 U.S. at 552.

$350 I d$. at 550.

351 Id. at 559.

352 See, e.g., Edward L. Rubin \& Malcom Feeley, Federalism: Some Notes on a National Neurosis, 41 UCLA L. REV. 903, 929 (1994). As Rubin and Feeley aptly explain, the other purported benefits of federalism can be obtained through a system of decentralization where the national government has the power to override the subunits. Id. at 921 .

353 United States v. Morrison, 529 U.S. 598, 616 (2000).

354 See Eid, supra note 298, at 1241 (arguing for a narrow interpretation of Congress's power over privately owned land).

355 See Goble, The Property Clause, supra note 7, at 1200.
} 
economic conduct, such as factory production, the disposal of products or waste in landfills, or even the use of electricity, has some attenuated effect on federal land. A sufficiently broad interpretation of Congress's power under the Property Clause thus "would erode those limits, permitting Congress to reach beyond the natural extent of its authority, 'everywhere extending the sphere of its activity and drawing all power into its impetuous vortex." "356 In sum, a broad reading of the Property Clause could erase Lopez, Morrison, and Sebelius by conferring on Congress the same type of unlimited federal police power that those cases rejected.

\section{B. Equal Sovereignty}

The Supreme Court's Property Clause doctrine is also at odds with its recent recognition of the equal sovereignty doctrine. In Shelby County v. Holder, the Court applied this doctrine to strike down a portion of the Voting Rights Act of 1965 (VRA). ${ }^{357}$ This legislation addresses the widespread problem of voter suppression. Although the Fifteenth Amendment was ratified in 1870, racial discrimination virtually rendered the amendment a nullity for nearly a century. ${ }^{358}$ In the rare instances where the courts struck down state policies, the states simply followed different discriminatory strategies "through unremitting and ingenious defiance of the Constitution." ${ }^{359}$ This racial discrimination was especially pronounced in the deep South, where white voter registration rates were more than fifty percent higher than those of African Americans. ${ }^{360}$

Congress enacted the Voting Rights Act of 1965 to address these problems and fulfill the promise of the Fifteenth Amendment. ${ }^{361}$ Section 2 of the VRA prohibits any "prerequisite to voting or standard, practice, or procedure" that "results in a denial or abridgment of the right of any citizen of the United States to vote on account of race or color." 362 Based on the history of southern defiance, however, Congress understood that the South might annul the effect of Section 2 by constantly changing their discriminatory tactics. Section 5 of the VRA therefore requires a three-judge federal district court in Washington or the Attorney General of the United States to approve any change in the election laws of selected jurisdictions that had a history of blatant racial discrimination. ${ }^{363}$

\footnotetext{
356 Nat'l Fed'n of Indep. Bus., 567 U.S. at 554-55 (quoting The Federalist No. 48, at 309 (James Madison) (N.Y. Packet, 1788)).

357 Shelby Cty. v. Holder, 570 U.S. 529, 542, 557 (2013).

358 See Michael J. Klarman, From Jim Crow to Civil Rights: The Supreme Court and THE StRUGGLE FOR RaCial EQUaLity 10-12 (2004).

359 South Carolina v. Katzenbach, 383 U.S. 301, 309 (1966).

360 See Guy-Uriel E. Charles \& Luis Fuentes-Rohwer, State's Rights, Last Rites, \& Voting Rights, 47 CONN. L. REV. 481, 493 (2014).

361 Voting Rights Act of 1965, Pub. L. No. 89-110, 79 Stat. 437 (current version at 52 U.S.C. $\$ 10301(2012))$.

36252 U.S.C. $\S 10301$ (a) (2012 \& Supp. II 2015).

363 Id. § 10304(a)-(d).
} 
Section 4(b) of the VRA selects jurisdictions for this preclearance system. ${ }^{364}$ It originally applied to each state or subdivision that used any "test or device" to determine voting eligibility and had less than fifty percent of the eligible population cast a ballot in $1964 .{ }^{365}$ Congress later updated the formula to include any jurisdiction that failed to meet this test in 1968 or $1972 .{ }^{366}$ When Congress reauthorized the VRA in 1982 and 2006, however, it did not update the coverage formula. ${ }^{367}$ Instead, the VRA allowed covered jurisdictions to "bail out" of coverage by showing a lack of recent discrimination. ${ }^{368}$ When Shelby County was decided by the Court in 2013, therefore, Alabama, Alaska, Arizona, Georgia, Louisiana, Mississippi, South Carolina, Texas, and Virginia were subject to preclearance based on data that had not been updated in decades. ${ }^{369}$

The Court in Shelby County struck down the application of Section 4(b)'s preclearance formula. The Court held that the preclearance system violated the " "fundamental principle of equal sovereignty' among the States." 370 Chief Justice Roberts explained that the VRA "sharply departs" from the principle of equal sovereignty because the "States must beseech the Federal Government for permission to implement laws that they would otherwise have the right to enact and execute on their own." 371 Because the VRA violates the doctrine of equal state sovereignty, the Court held, the VRA's differential treatment "must be 'sufficiently related to the problem" " of voting discrimination. ${ }^{372}$ The Court ultimately concluded that application of the preclearance formula was unconstitutional because it could not even survive rational basis review. ${ }^{373}$ Because the formula relied solely on conditions from the 1960s and 70s, the Court held, the VRA's limitation of the sovereignty of the covered states did not "make[] sense in light of current conditions." 374

Scholars have almost universally criticized Shelby County's equal sovereignty doctrine and especially its application to legislation passed under the Reconstruction Amendments. ${ }^{375}$ However, as documented here and more fully explored elsewhere, ${ }^{376}$ scholars are wrong to suggest that the equal sovereignty

\footnotetext{
364 Id. $\S 10303(\mathrm{~b})$.

365 Id.

366 Voting Rights Act Amendments of 1975, Pub. L. No. 94-73, 89 Stat. 400, 402 (current version at 52 U.S.C. $\S 10303(b)(2012))$.

367 See 52 U.S.C. $\$ 10303(a)(7)-(8)(2012)$.

368 See Shelby Cty. v. Holder, 570 U.S. 529, 537 (2013) (citations omitted).

369 See id. at 551, 553.

370 See id. at 544, 557 (citations omitted).

371 Id. at 544.

372 See id. at 550-51 (internal citations omitted).

373 See Jeffrey M. Schmitt, In Defense of Shelby County's Principle of Equal State Sovereignty, 68 OKLA. L. REV. 209, 218-19 (2016).

374 Shelby Cty., 570 U.S. at 551, 553, 557.

375 See Schmitt, supra note 373, at 210-12 (collecting citations to Shelby County's critics).

376 See id.
} 
doctrine lacks historical support. ${ }^{377}$ Scholarly claims that the Court in Shelby County "invented" equal sovereignty are tenable only by myopically focusing on Supreme Court precedent on the equal footing doctrine. ${ }^{378}$ And yet, it is fair to take the Court to task for applying the equal sovereignty doctrine to limit Congress's power to enforce the Reconstruction Amendments while giving Congress an unlimited legislative power over nearly one-third of the country, most of which is located within a small number of Western states. As demonstrated above, equal sovereignty arguments originated in debates over the public lands and were rebuffed by congressmen who disclaimed any federal regulatory power over U.S. lands within the states. It is therefore anomalous for the Court to recognize the equal sovereignty principle while maintaining that Congress has unlimited regulatory power under the Property Clause.

\section{POLICY IMPLICATIONS}

\section{A. The Property Clause and Environmental Law}

This Article's interpretation of the Property Clause is defensible from the standpoint of practical policy concerns. In sum, limiting the Property Clause would change the status quo only in the rare instances where the Commerce Clause does not justify a federal regulation. When the Property Clause is the sole basis of federal authority, this Article's approach would require all land uses to be consistent with both federal and state policy. States like California would therefore have a newfound power to prevent environmental degradation

377 Ablavsky is one of the few modern scholars to recognize the historical support for the equal sovereignty doctrine. See Ablavsky, supra note 7, at 689. He argues, however, that the Court's adoption of the doctrine as a limit on congressional power is misguided because history shows that disputes over the equal sovereignty doctrine were debated and resolved in Congress rather than the courts. See id. at 688. Ablavsky's argument, however, is inconsistent with the Supreme Court's modern approach to federalism. Although many scholars have suggested that the Court's federalism doctrines are misguided because the political process protects state sovereignty, see Herbert Wechsler, The Political Safeguards of Federalism: The Role of the States in the Composition and Selection of the National Government, 54 Colum. L. Rev. 543, 543 (1954), the Court has long rejected this approach. Modern federalism doctrine is instead animated by a belief that "the limitation of congressional authority is not solely a matter of legislative grace." United States v. Morrison, 529 U.S. 598, 616 (2000) (citations omitted). Moreover, Congress was the primary forum for constitutional debate in the early nineteenth century. Numerous constitutional issues, such as the scope of implied powers, electoral issues, tribal sovereignty, and even the nature of judicial review were extensively debated in the halls of Congress. See, e.g., David P. CURrie, The Constitution IN Congress: Democrats and Whigs 1829-1861 184 (2005); David P. Currie, The Constitution in Congress: Descent into the Maelstrom 1829-1861 151 (2005); DAvid P. Currie, The Constitution in Congress: The Federalist Period 1789-1801 81, 85, 136-37, 144 (1997); CURRIE, supra note 72, at 46. No one would suggest that such congressional debate somehow removes these issues - or the doctrines discussed during the debates-from the purview of the Supreme Court.

378 See Leah M. Litman, Inventing Equal Sovereignty, 114 Mich. L. REV. 1207, 1228 (2016). 
on federal land within their borders. ${ }^{379}$ Because the states lack the power to seize federal land through eminent domain, ${ }^{380}$ however, state power would be asymmetrical. Although the states could veto environmentally harmful activities on federal land, they would otherwise be unable to override federal policy. Just like any other landowner, the federal government would still retain the power to exclude polluters or companies that seek to extract resources, even over state objections. This asymmetry may be desirable because, as the current crisis over climate change demonstrates, we often have incentives to overdevelop at the expense of the long-term public good. ${ }^{381}$

When the first major environmental statutes were passed during the 1970s, the Commerce Clause appeared to provide a solid foundation. ${ }^{382}$ Clean air, clean water, and even biodiversity all have a substantial effect on interstate commerce, at least in the aggregate. Since the Court limited the reach of the Commerce Clause to economic activity in Lopez, however, there has been considerable academic debate over whether these laws remain fully justified. ${ }^{383}$ Environmental legislation is often not commercial in nature and sometimes regulates activities that appear to be no more economic than the conduct at issue in Lopez or Morrison.

This is especially true for the Clean Water Act (discussed in this Article's introduction) and the Endangered Species Act (ESA). ${ }^{384}$ The purpose of the ESA is to protect endangered and threatened species and the ecosystems that they rely upon. ${ }^{385}$ The ESA achieves this goal by, among other things, protecting the species and their habitats from federal action and prohibiting anyone from "taking" protected animals. ${ }^{386}$ The "taking" provision has been broadly interpreted to include not only directly harming a protected animal, but also modifying its habitat in a way that causes such harm. ${ }^{387}$

379 California has recently been noted for using its state powers to challenge federal authority under the Trump Administration. See, e.g., Katy Steinmetz, 7 Ways California is Fighting Back Against President Trump's Administration, TIME (Apr. 6, 2017), http://time.com/472 5971 [https://perma.cc/E7WA-KEFK].

380 See Gibson v. Chouteau, 80 U.S. (13 Wall.) 92, 99 (1871).

381 See Therese Strand, Short-termism in the European Union, 22 Colum. J. Eur. L. 15, 18 (2015) (discussing how short-term economic incentives can create suboptimal long-term environmental impacts).

382 See, e.g., James R. May, Healthcare, Environmental Law, and the Supreme Court: An Analysis Under the Commerce, Necessary and Proper, and Tax and Spending Clauses, 43 LEWIS \& CLARK L. SCH. ENVTL. L. 233, 245 (2013).

383 See, e.g., John C. Eastman, A Fistful of Denial: The Supreme Court Takes a Pass on Commerce Clause Challenges to Environmental Laws, 2003-2004 CATO SuP. CT. ReV. 469, 469; Klein, supra note 14, at 1; May, supra note 382, at 247.

384 Endangered Species Act, 16 U.S.C. $§ \S 1531-44$ (2012 \& Supp. V 2017).

385 Id. $\S 1531(\mathrm{~b})$.

${ }^{386} I d . \S 1538(\mathrm{a})(1)(\mathrm{B})-(\mathrm{C})$.

38750 C.F.R. $\S 17.3$ (2018). 
Although the lower courts continue to uphold the ESA, 388 its constitutionality under the Commerce Clause is far from clear in every application. The habitats of roughly half of the endangered or threatened species covered under the act are located within a single state, and most of the animals have little or no commercial value. ${ }^{389}$ It would therefore be possible for a court to conclude that the protection of endangered species is no more economic than the gendermotivated violence or gun possession that was struck down in Morrison and Lopez. In fact, several lower court judges who have directly confronted the issue have suggested that some applications of the ESA would be unconstitutional. ${ }^{390}$

In Rancho Viejo, L.L.C. v. Norton, for example, a real estate developer's plan for a massive housing development threatened the existence of the arroyo southwestern toad. ${ }^{391}$ The toad has no commercial value, the threatened habitat was located solely within California, and the toad rarely travels more than a mile from its habitat. ${ }^{392}$ The D.C. Court of Appeals upheld the application of the ESA to block the developer's plan, but Chief Judge Ginsburg wrote separately to stress her view that, "with respect to a species that is not an article in interstate commerce and does not affect interstate commerce, a take can be regulated if-but only if - the take itself substantially affects interstate commerce." ${ }^{393}$ Ginsburg joined the court's opinion only because the regulated activity was "large-scale residential development." 394 However, she stated, "the lone hiker in the woods, or the homeowner who moves dirt in order to landscape his property, though he takes the toad, does not affect interstate commerce." ${ }^{395}$ It is possible that the same could be said for other private takings by outdoor enthusiasts without a commercial motive, such as the recreational fisherman, hunter, or camper.

Although there are thus plausible arguments against the constitutionality of some applications of the ESA, this Article takes no position on their validity. The Supreme Court's opinion in Gonzales v. Raich potentially supports the constitutionality of the ESA in whole. ${ }^{396}$ The Court in Raich upheld the application of the Controlled Substances Act (CSA) to the intrastate home-growth

388 See GDF Realty Inv., Ltd. v. Norton, 326 F.3d 622, 624, 640-41 (5th Cir. 2003); Rancho Viejo, L.L.C. v. Norton, 323 F.3d 1062, 1064, 1080 (D.C. Cir. 2003); Gibbs v. Babbitt, 214 F.3d 483, 486-87 (4th Cir. 2000); Nat'l Ass'n of Home Builders v. Babbitt, 130 F.3d 1041, 1052 (D.C. Cir. 1997).

389 See Bradford C. Mank, After Gonzales v. Raich: Is the Endangered Species Act Constitutional Under the Commerce Clause?, 78 U. Colo. L. REV. 375, 428 (2007).

390 See GDF Realty Inv., Ltd., 326 F.3d at 640; Rancho Viejo, L.L.C., 323 F.3d at 1077-78; Gibbs, 214 F.3d at 503-04; Nat'l Ass'n of Home Builders, 130 F.3d at 1052.

391 Rancho Viejo, L.L.C., 323 F.3d at 1064.

392 Id. at 1065.

393 Id. at 1080 (Ginsburg, J., concurring).

394 Id.

395 Id.

396 Gonzales v. Raich, 545 U.S. 1, 22 (2005); see Mank, supra note 389, at 429. 
and use of medical marijuana in California. ${ }^{397}$ The Court in Raich reasoned that enforcement against medical marijuana was constitutional because it was a necessary part of a comprehensive regulatory scheme (the CSA) that was justified under the Commerce Clause. ${ }^{398}$ Although a full discussion is beyond the scope of this Article, similar logic potentially could be used for the ESA. ${ }^{399}$

Even if federal environmental legislation like the ESA is sound under the current doctrine, it is always possible that the Supreme Court will further narrow the Commerce Clause. In fact, with Justice Kennedy's retirement and the appointment of Justice Kavanaugh, such a move would not be completely unexpected. The federalism revolution of the last few decades has been a product of the right, and studies consistently show that Kavanaugh is to the right of Kennedy on most issues. ${ }^{400}$ In fact, prominent conservative academics have called for the new Court to further limit federal power, including in the sphere of the Commerce Clause and environmental law. ${ }^{401}$

If the Supreme Court were to hold that the Commerce Clause cannot justify the application of a federal environmental law, the Property Clause is another potential source of authority. In fact, several scholars argue that the Property Clause currently removes any constitutional doubt regarding federal power over the environment. ${ }^{402}$ Some scholars even contend that the Property Clause justifies federal regulation of anything that, in the aggregate, could have an effect on federal land. ${ }^{403}$

Under this Article's interpretation of the Property Clause, even where the Commerce Clause does not apply, Congress would still have the power to enact environmental regulations protecting federal land. As the Court held in preNew Deal cases like Camfield, Congress can exclude people, corporations, and specific activities from its lands just like any other landowner. ${ }^{404}$ In fact, because the power to regulate is typically used to limit or prohibit, Congress's power as a proprietor would not be dramatically different from a sovereign power to regulate. Just as a proprietor can deny permission to a company that seeks to conduct fracking or drill for oil on her privately owned land, Congress could use its proprietary powers to prohibit such activities on U.S. lands.

The key distinction between regulatory and proprietary power is whether Congress has the ability to preempt state legislation. Pursuant to the Supremacy

397 Raich, 545 U.S. at 9.

398 Id. at 22.

399 For more on Raich and the ESA, see generally, Mank, supra note 389.

400 See, e.g., Oliver Roeder, How Kavanaugh Will Change the Supreme Court, FiveTHIRTYEIGHT (Oct. 6, 2018), https://fivethirtyeight.com/features/how-kavanaugh-will-c hange-the-supreme-court [https://perma.cc/SXB8-M28Z].

401 See John Yoo \& James C. Phillips, The Supreme Court Should Make Politics Local Again, NAT'L REV. (Jan. 15, 2019) https://www.nationalreview.com/2019/01/supreme-court [https://perma.cc/9V9J-Z3KK].

402 See Appel, supra note 7, at 7-8; Goble, The Property Clause, supra note 7, at 1200; Owley, supra note 7 , at 38 .

403 See Appel, supra note 7, at 127-30; Goble, supra note 7, at 1234-35.

404 Camfield v. United States, 167 U.S. 518, 521 (1897). 
Clause, federal regulations preempt any conflicting state legislation. ${ }^{405}$ An ordinary proprietor, however, lacks the power to overrule valid state law. Acting only as a proprietor of federal land, Congress would thus lack the power to authorize the destruction of the habitat of a threatened species or the pollution of an intrastate wetland if prohibited by state law. Limiting the Property Clause would thus preserve federal authority while also empowering the states to provide a check on federal standards. ${ }^{406}$

While this Article's interpretation of the Property Clause would give the states the power to protect the environment from federally authorized activities, it would not allow states to undermine federal protections for U.S. land. This is true because of the nature of federal title. Unlike an ordinary landowner, Congress has always had an unlimited power to retain and dispose of federal land without any interference from the states. ${ }^{407}$ Even under a limited interpretation of the Property Clause, the states thus could not take federal land, authorize private parties to interfere with federal land rights, or assess property taxes on the United States. Unlike with a private landowner, therefore, the states cannot overrule federal land use restrictions by interfering with federal property rights. For example, a state cannot use its eminent domain power to seize federal lands for development. As a result, limiting the Property Clause would not empower the states to roll back environmental protections for federal lands.

Providing the states and federal government with overlapping power would therefore structurally favor conservation over development. Our federally dominated system has worked reasonably well only because the federal government has aggressively sought to protect the environment since the 1970 s. ${ }^{408}$ Even when the executive has been less inclined towards environmental protection, such as during the Trump administration, ${ }^{409}$ Congress has not dramatically changed the law. The Courts thus often block executive action that exceeds statutory authorization. ${ }^{410}$ But suppose that Congress scrapped environmental legislation and declared open season for pollution, development, and resource extraction. Under modern doctrine, the states would be powerless to stop the resulting environmental harm. Modern environmental federalism is thus not in-

405 See, e.g., Murphy v. NCAA, 138 S. Ct. 1461, 1476 (2018).

406 Of course, many states might not be interested in strengthening environmental protections. See Alejandro E. Camacho \& Michael Robinson-Dorn, Turning Power Over to States

Won't Improve Protection for Endangered Species, Conversation (Jan. 11, 2018), $\mathrm{http}$ ://theconversation.com/turning-power-over-to-states-wont-improve-protection-forendangered-species-87495 [https://perma.cc/TA3G-8BC9].

407 Schmitt, supra note 7, at 478 .

408 See Buzbee, supra note 21, at 111.

409 See Doyle, supra note 23.

410 See Oliver Milman, 'Sloppy and Careless': Courts Call Out Trump Blitzkrieg on Environmental Rules, GUARDIAN (Feb. 20, 2018), https://www.theguardian.com/environment/20 18/feb/20/donald-trump-epa-environmental-rollbacks-court-challenges [https://perma.cc/6576-6ZU5]; Ari Natter, Back-to-Back Court Losses Show Limits of Trump Deregulation, BlOOMBERG: Politics (Aug. 19, 2018), https://www.bloomberg.com/news/art icles/2018-08-19/back-to-back-court-losses-show-limits-of-trump-s-deregulations [https://perma.cc/6ECC-7BKJ]. 
herently disposed to environmental protection; instead, it has served environmental interests only because the federal government has been disposed to do so up to this point.

Indeed, "environmental federalism" is a misnomer. ${ }^{411}$ Because the states have no more independence than the federal government allows, there is no actual split of sovereign authority. ${ }^{412}$ Although federal law usually permits the states to strengthen environmental protections, ${ }^{413}$ Congress always retains the power to overrule state law. Federal policy — good or bad — can therefore potentially always control. By preserving state sovereignty, a limited reading of the Property Clause would empower states to veto destructive federal policy.

\section{B. Other Issues: Federal Land Ownership, Tribal Sovereignty, and Other Social Issues}

Several legal scholars contend that, under the original meaning of the Property Clause, Congress not only has a "power to dispose of" federal land, but it also has a duty to do so. ${ }^{414}$ Such scholarship provides the academic foundation for legislation such as Utah's Transfer of Public Lands Act, which demands that the federal government transfer title to more than twenty-million acres of land to the state. ${ }^{415}$ Although such state legislation is preempted by federal law, the Republican platform and many national party leaders have endorsed transferring at least some significant portion of federal land to the states. ${ }^{416}$

This Article's proposed limitation of the Property Clause, however, would have no effect on federal land ownership. As I have argued elsewhere at length, federal land ownership is fully consistent with constitutional history. ${ }^{417}$ When the meaning of the Property Clause was first debated in Congress, the leading statesmen of the day argued that unqualified federal land ownership was constitutional because it did not carry a national police power into the territory of the states. Returning to the original understanding of the Property Clause thus would not support state demands for federal land. By the same logic, however, it also would not save California's recent attempt to limit the federal govern-

411 The topic of environmental federalism is discussed in numerous books and journal articles, see, e.g., Kalyani RobBins, The Law and Policy of Environmental Federalism ix (2015); Christine A. Klein, supra note 14, at 1.

412 For a discussion of the core meaning of federalism, see supra Section IV.A.

413 See Buzbee, supra note 21, at 126-27.

414 See Brodie, supra note 7, at 694; Landever, supra note 7, at 578-79; Robert G. Natelson, Federal Land Retention and the Constitution's Property Clause: The Original Understanding, 76 U. CoLo. L. REV. 327, 377 (2005).

415 See Transfer of Public Lands Act, H.B. 148, 59th Leg., Gen. Sess. (Utah 2012) (codified as UTAH CODE ANN. §§ 63L-6-101 to 63L-6-104 (2017)).

416 See Schmitt, supra note 7, at 511.

417 Id. at 456-57. 
ment's power to sell land to private parties. ${ }^{418}$ Congress's power to retain or sell the federal lands would remain unlimited.

This Article's interpretation of the Property Clause would also have no effect on federal Indian law. The Court has long held that the tribes are " "domestic dependent nations,' subject to plenary control by Congress." 419 In U.S. v. Lara, the Court stated that Congress's "broad general powers to legislate in respect to Indian tribes" derive from a combination of the Indian Commerce Clause, the treaty power, and inherent military and foreign affairs powers that are "necessary concomitants of nationality." ${ }^{420}$ Notwithstanding the obvious connections, ${ }^{421}$ the Property Clause is thus not a basis of federal power over the Indian tribes. A limited reading of the Property Clause would therefore not empower the states to interfere with federal Indian law.

This Article's interpretation, however, would prevent Congress from abusing its Property Clause power by overruling the states on a range of other social issues. As discussed in the Introduction, the Court's current interpretation of the Property Clause empowers Congress to unilaterally seize land within a state and place it beyond the state's control. Although the Property Clause is often associated with environmental law, there is nothing in the doctrine to stop Congress from using the Clause to create havens where people are exempt from state law. Congress therefore could effectively overrule state policies on issues such as the treatment of detained migrant children, abortion, gambling, or physician-assisted suicide. Under the original understanding of the Constitution, Congress must obtain the consent of the states under the Enclave Clause before obtaining such power. This Article's interpretation of the Property Clause would thus preserve state sovereignty over internal affairs.

State sovereignty, of course, is not an unmitigated good. Most Americans (including the author) believe that empowering the states to outlaw abortion would constitute bad policy. ${ }^{422}$ States' rights ideology also was used to justify the evils of slavery, secession, and Jim Crow. ${ }^{423}$ And yet, federalism has also been used to justify antislavery opposition to the Fugitive Slave Act and state sanctuary policies that seek to ameliorate some of the harsh consequences of

418 See Lisa Belenky \& Kim Delfino, SB 50: California Sets a Course to Keep Public Lands Public, A.B.A. Sec. Env'T, Energy, \& Resources: Trends (Nov. 9, 2018). The California legislation would require private purchasers to give the state a right of first refusal before purchasing any federal land. A federal district court, however, has enjoined enforcement of the law under the intergovernmental immunities doctrine. See Memorandum and Order at 18, United States v. Cal. State Lands Comm'n, No. 2:18-cv-721-WBS-DB, 2018 WL 5780003, at *8 (E.D. Cal. Nov. 1, 2018).

419 Puerto Rico v. Sanchez Valle, 136 S. Ct. 1863, 1872 (2016) (quoting United States v. Lara, 541 U.S. 193, 204 (2004)).

${ }^{420}$ United States v. Lara, 541 U.S. 193, 200-01 (2004) (quoting United States v. CurtissWright Export Corp., 299 U. S. 304, 315-22 (1936)).

421 See supra Section II.D.

422 See Maggie Fox, Most Americans Want Roe v. Wade to Stand, Survey Shows, NBC News: Health News (June 29, 2018), https://www.nbcnews.com/health/health-news/mostamericans-want-roe-v-wade-stand-survey-shows-n887751 [https://perma.cc/UJJ8-9BPY].

423 See, e.g., Schmitt, supra note 373, at 243, 258-61. 
federal immigration enforcement. ${ }^{424}$ In sum, federalism is a system of government that empowers a local majority to pass laws that are at odds with federal policy. The normative desirability of federalism depends on who is in power in the federal government.

\section{CONCLUSION}

The Supreme Court should overrule its broad interpretation of Congress's power under the Property Clause. A deep dive into constitutional history shows that, when the nation first grappled with the issue in the early nineteenth century, the leading statesmen of the day all rejected an expansive interpretation of federal power over the public lands. Federal landownership was consistent with a republic of equal states, they argued, only because it did not displace the primacy of state sovereignty over most issues. When the Supreme Court's early precedent - including the infamous Dred Scott decision - are read in context, they reveal that the Court shared this understanding of the Property Clause. Although federal land ownership is fully consistent with constitutional history, the modern doctrine otherwise has no historical support prior to the New Deal era.

The Court's interpretation of the Property Clause is also inconsistent with modern constitutional law. Over the past several decades, the Court has limited federal power, most notably under the Commerce Clause, to preserve a sphere of autonomy for the states. A broad interpretation of the Property Clause, however, could easily allow Congress to bypass such limitations and undermine state policy. The Court's Property Clause doctrine is especially inconsistent with the Court's recent recognition of the equal state sovereignty principle, which first emerged during the debates over the public lands.

Advocates of environmental regulation should not reject this Article's approach to Congress's Property Power out of hand. Congress could continue to regulate activities on federal land as a landowner. This Article's interpretation of the Property Clause would simply empower the states to act as an additional check. Because the states cannot interfere with federal title, they could not seize federal land and authorize new land uses over federal objections. The Article's approach would thus structurally favor conservation over development. On other matters, the normative desirability of empowering the states would depend on who is in office.

${ }^{424}$ See Jeffrey M. Schmitt, Immigration Enforcement Reform: Learning from the History of Fugitive Slave Rendition, 103 Geo. L.J. ONLINE 1, 2 (2014). 